The Effect of Composition and Thickness on the Mechanism and Kinetics of Filiform Corrosion occurring on Zinc-Aluminium-Magnesium coated steel

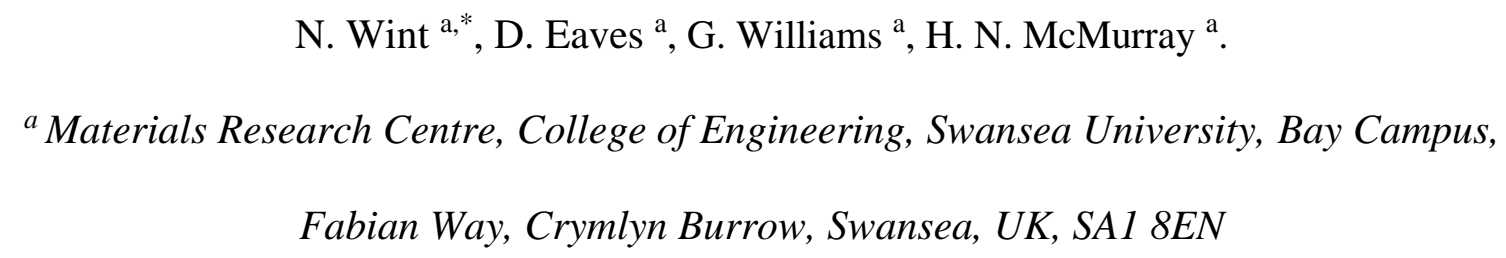
Fabian Way, Crymlyn Burrow, Swansea, UK, SA1 8EN

\title{
4 Abstract:
}

5 The effect of coating thickness and composition on the kinetics of acetic acid-induced 6 filiform corrosion (FFC) on Zinc-Aluminium-Magnesium (ZAM) coated steel is 7 investigated. Scribe defects are created in organic coatings applied to $\sim 10 \mu \mathrm{m}$ coatings of

8 varying composition (1-6 wt.\%. Al, 1-3 wt. \% Mg), and fixed composition (Zn-1.5 wt. \%

9 Al- 1.5 wt. $\% \mathrm{Mg}$ ) but varying thickness $(5-27 \mu \mathrm{m})$. FCC decreases with increasing $\mathrm{Al}$ (at

10 fixed wt. $\% \mathrm{Mg}$ ) and thickness. A linear trend exists between thickness and iron exposure

11 time. Findings are consistent with FFC advancing via a penetrative coating mechanism

12 whereby exposed iron couples to the coating.

13 Keywords; A Steel A Magnesium A Metal Coatings C Atmospheric Corrosion C

\section{Polymer Coatings.}

26 *Corresponding author:

27 E-mail address: n.wint@swansea.ac.uk 


\section{Introduction}

29 Metallic coatings based on Zn alloyed with Al and Mg (e.g. SuperDyma® Zn-11 wt.\%Al-

$303 \mathrm{wt} . \% \mathrm{Mg}$ ) have been used for the cathodic protection of steel for several decades. In more

31 recent years, the reduced corrosion-driven mass loss associated with zinc-aluminium-

32 magnesium (ZAM) coated steel (compared to Zn coated steel of similar thickness) [1] has

33 helped drive an increase in the production of $\mathrm{Zn}$ coatings which incorporate lower amounts

34 of alloying addition ( 0.1-3.5 wt. \% $\mathrm{Mg}$ and 0.1-3.5 wt. \% $\mathrm{Al})$ and can therefore be used

35 for more widespread applications. However, a large proportion of the ZAM hot dip

36 galvanised steel used in service is overcoated with organic coatings. Organic coating failure

37 can occur in the presence of penetrative coating defects which allow aggressive electrolytes

38 to come into contact with the metal substrate [2]. Cathodic disbondment and filiform

39 corrosion (FFC) are two specific modes of corrosion driven organic coating delamination

40 arising from differential aeration phenomena, which both occur under atmospheric

41 corrosion conditions at high relative humidity [2]. In the case of cathodic delamination, it

42 is cathodic oxygen reduction reaction (ORR) which is responsible for disbondment of the

43 organic coating from the metal substrate, and only group I cations possess the hydrolytic

44 stability and solubility necessary to support the strongly alkaline electrolyte necessary [2-

45 4]. Whilst organic coating failure via cathodic delamination has been reported to occur on

46 zinc [5-9], $\mathrm{MgZn}_{2}$ (one of the predominant phases present within ZAM alloys) [10-13] has

47 been shown to resist cathodic delamination [14-17]. This finding was (primarily) attributed

48 to an inversion of the normal difference in electrochemical potential observed between the

49 anodically active defect and the intact organic coated $\mathrm{MgZn}_{2}$ surface [14-17]. Elsewhere,

$50 \quad 1.5$ wt. $\% \mathrm{Al}, 1.5 \mathrm{wt}$ \% $\mathrm{Mg}$ coatings were found to exhibit a high resistance to corrosion

51 driven delamination of an organic (PVB) overcoat film [18]. This finding was believed to 
52 be a result from the presence of $\mathrm{Mg}-\mathrm{Zn}$ and $\mathrm{Mg}-\mathrm{Al}-\mathrm{Zn}$ eutectic phases in the coating

53 microstructure. These phases are predicted to have low activity for cathodic $\mathrm{O}_{2}$ reduction.

54 The presence of eutectic therefore renders the principle $\mathrm{O}_{2}$ reduction cathode (primary zinc)

55 discontinuous and inhibits the movement of the cathodic disbondment front [18].

56 In comparison, acetic acid, $\mathrm{CH}_{3} \mathrm{COOH}$ (which will from this point be referred to as $\mathrm{HAc}$ )

57 induced FFC has recently been shown to be an important mode of the corrosion driven

58 organic coating failure on ZAM [18]. FFC is a form of anodic disbondment which occurs

59 when an aggressive electrolyte comes into contact with the metal substrate at defects in the

60 organic coating [2]. FFC presents as tracks of corrosion product which propagate under the

61 organic coating and lengthen with time. The electrolyte is contained within the filament

62 head at which anodic dissolution occurs [19-21]. The anodic dissolution is coupled to the

63 cathodic ORR, which occurs primarily at the rear of the head where water-insoluble metal

64 oxides and hydroxides are formed. Williams and McMurray observed an area of cathodic

65 delamination preceding filiform corrosion but contest its role as a primary cathode and

66 claim it plays no role in the mechanism of filiform advance [22]. Watson used in-situ

67 timelapse optical microscopy to gain a mechanistic understanding of filiform in a dual

68 compartment cell in which independent control of the areas surrounding the head and the

69 tail. Watson confirms presence of a cathode around the head, suggesting that the annulus

70 of dark corrosion product observed is the result of cathodic activity, but states that the

71 constant filament speed observed suggests there is no mass transport limitation on

72 propagation [23]. FFC then propagates via differential aeration [19-24]. Although $\mathrm{FeCl}_{2}$,

$73 \mathrm{NaCl}$ and $\mathrm{HCl}$ have been shown to act as initiators of FFC on iron [22-23, 25] and

74 aluminium [24, 26-32], and magnesium [33], only HAc has been found to reliably and

75 reproducibility produce FFC on ZAM coatings [18]. HAc is known to be one of the most 
76 ubiquitous initiators of atmospheric corrosion which occurs on materials exposed to indoor

77 environments and it is emitted during several important technological and biological

78 processes [34-42]. Although FFC has not, as far as is known, been observed to occur on

79 ZAM exposed to HAc when used within indoor environments, the mechanism of failure

80 via FFC is of scientific and industrial interest. In this paper we present an investigation into

81 the effect of both ZAM coating thickness, and composition, on HAc induced FFC, with the

82 aim of further elucidating the mechanism by which it occurs.

83 The principal component making ZAM susceptible to HAc induced FFC is assumed to be

$84 \mathrm{MgZn}_{2}$ (present in the eutectic phases of the microstructure), an intermetallic which has

85 been shown to be attacked at the front of an advancing filament head [18]. FFC

86 advancement is then hypothesized to proceed by a penetrative through coating mechanism

87 in which anodic dissolution of the $\mathrm{Mg}$ rich phases allows $\mathrm{O}_{2}$ percolation to $\mathrm{Fe}$ substrate,

88 which acts as the FFC cathode. If this hypothesis were true, then an inverse relationship

89 would exist between coating thickness and FFC area rate (i.e. the increased charge required

90 for dissolution of thicker coatings will result in reduced rates of propagation). The effect

91 of a systematic change in coating thickness (coating weight), on FFC growth kinetics, can

92 therefore be studied with the aim of confirming the mechanism by which FFC propagates

93 on ZAM.

94 A question then arises as to whether the ZAM composition may be changed in such a way

95 as to decrease the rate of iron exposure. For example, $\mathrm{Al}$ resists the action of HAc at room

96 temperature and has been used for the transportation and storage of acetic acid. It therefore

97 seems plausible that HAc induced dissolution of ZAM may be decreased by increasing the

$98 \mathrm{Al}$ content [43]. In comparison, magnesium acetate is highly soluble in water [44] and zinc

99 hydroxyacetate salts [44-45] tend to decompose through hydrolysis at room temperature, 
100 releasing acetate. Alloying of $\mathrm{Zn}$ based coatings, with elements such as $\mathrm{Al}$ and $\mathrm{Mg}$, results

101 in the creation of different phases of different sizes, shapes, distribution and proportion,

102 and small differences in composition result in variations in the behavior of localized

103 corrosion [46-47]. Localized attack results in non-uniform distribution of $\mathrm{pH}$ and

104 electrolyte composition, which in turn determine the stability of the corrosion product

105 formed [48-49].

106 The effect of coating composition on the kinetics and mechanism of corrosion on bare

107 galvanized steel (without an organic overcoat) has been thoroughly studied in a range of

108 environments [1, 10-11, 14-17, 46-70]. Phases which contain Al are considered stable

109 compared to the zinc matrix $[11,50-51,56]$ whilst $\mathrm{Mg}$ containing phases (e.g. $\mathrm{MgZn}_{2}$ and

$\left.110 \mathrm{Mg}_{2} \mathrm{Zn}_{11}\right)$ preferentially corrode $[1,11,50-51,56] . \mathrm{Mg}(\mathrm{OH})_{2}$, formed by reaction of the

$111 \mathrm{Mg}^{2+}$ ions (released during dissolution) and $\mathrm{OH}^{-}$ions (produced at the cathode), replaces

112 zinc (hydr)oxide on the ZAM surface $[14,52,65]$. The presence of $\mathrm{Mg}(\mathrm{OH})_{2}$ is believed to

113 reduce the ORR rate $[14,55]$, and to 'buffer' the electrolyte $\mathrm{pH}$ such as to stabilize

114 protective hydrozincite $\left(\mathrm{Zn}_{5}\left(\mathrm{CO}_{3}\right)_{2}(\mathrm{OH})_{6}\right)$ and simonkolleite $\left(\mathrm{Zn}_{5}(\mathrm{OH})_{8} \mathrm{Cl}_{2} \bullet\left(\mathrm{H}_{2} \mathrm{O}\right)\right)$ [50,

115 54]. The addition of $\mathrm{Al}$ to $\mathrm{Zn}$ alloy coatings results in a modification to the morphology

116 and stability of zinc corrosion product $(\mathrm{ZnO})$ [49], which becomes more compact and

117 enriched in aluminium [62] and the corrosion product formed on $\mathrm{Zn}-\mathrm{Al}-(\mathrm{Mg})$ coatings has

118 been shown to be dependent on $\mathrm{Al}^{3+}$ concentration [70]. Aluminates, can also react with

$119 \mathrm{Mg}^{2+}$ ions to form layered double hydroxides (LDH) which remain stable up to $\mathrm{pH} 12$ [1,

$12050,52,62]$. The mass lost from HDG and various $\mathrm{Zn}-\mathrm{Al}, \mathrm{Zn}-\mathrm{Mg}$ and $\mathrm{Zn}-\mathrm{Al}-\mathrm{Mg}$ coatings,

121 pre-deposited with $\mathrm{NaCl}$ and stored in humid air, has been shown to be lowest for the most

122 highly alloyed samples [55]. 
123 In comparison, work pertaining to the ability of $\mathrm{Zn}$ alloys to resist corrosion driven organic

124 coating failure is limited, and primarily focuses on $\mathrm{Zn}-\mathrm{Mg}$ alloys. For example, the cathodic

125 delamination of PVB from PVB Zn-Mg films of varying composition has been investigated

126 using in situ Kelvin probe [60]. Whilst cathodic disbondment was observed at $\mathrm{Mg}$

127 compositions of $\leq 5 \mathrm{wt}$. \% w/w, $\mathrm{Zn}-\mathrm{Mg}$ coatings in the range 10-25 wt. \% were shown to

128 resist delamination for periods of up to $48 \mathrm{~h}$. In comparison, $\mathrm{Mg}$ compositions of $\geq 12$

129 wt. \% were instead susceptible to coating failure by anodic undermining [60]. A thorough

130 investigation into the effect of ZAM composition on the corrosion of organically coated

131 ZAM has not been completed. It has also been shown that changing the amount of $\mathrm{Al}$ and

$132 \mathrm{Mg}$ within the range 1-2 wt. \% does not result in any major differences in scribe creep

133 [71]. The current work therefore aims to address the lack of knowledge in how ZAM

134 composition influences the rate of organic coating failure rates, especially when anodic

135 disbondment is the prevailing one.

136 The aim of this paper is two-fold. Firstly, to confirm that the rate of FFC propagation on

137 ZAM is proportional to the time to iron (substrate) exposure. Secondly, to determine

138 whether the relative amount of each ZAM element can be modified in such a way as to

139 decrease the rate of iron exposure, and thus FFC propagation. In so doing Zn-1.5 wt.\% Al-

1401.5 wt. \% Mg coating weight (thickness) is systematically varied and FFC is initiated via

141 the application of small, controlled, quantities of $1.5 \mathrm{~mol} . \mathrm{dm}^{-3} \mathrm{HAc}$ to a penetrative defect

142 in the polyvinyl butyral co-vinyl alcohol-co-vinyl acetate (PVB) coating, followed by

143 incubation at a controlled relative humidity. The rate of FFC propagation is determined as

144 a function of ZAM coating weight (thickness) and correlated with iron substrate exposure

145 time, as determined by immersing the different coated samples in HAc for varying periods

146 of time. A similar study is completed whereby the Al content of a $10 \mu \mathrm{m}$ thick ZAM coating 
147 is changed between 1-6 wt.\%. Al. The composition range used is representative of the

148 compositions which are commercially available, and as such, the amount of $\mathrm{Mg}$ contained

149 within the alloy also varies in some cases. Nevertheless, it is still possible to complete a

150 systematic investigation into the effect of wt. \% Al, on FFC rate.

\section{2. Materials and Methods}

\section{$152 \quad 2.1$ Materials}

153 Two sets of Zn-Al-Mg coated steel were supplied by Tata Steel. In the case of the first set,

154 the $0.7 \mathrm{~mm}$ gauge mild steel was coated with a $\sim 10 \mu \mathrm{m}$ thick $\left(140 \mathrm{~g} \cdot \mathrm{m}^{-2}\right)$ ZAM layer of

155 varying composition (see Table 1 which also gives denominations which will be used for

156 the remainder of this work) on each side. For the second set the coating composition (1.5Al-

$157 \quad 1.5 \mathrm{Mg}$ ) was kept the same whilst the coating weight (thickness) was varied between 70

158 g.m $\mathrm{m}^{-2}$ and 350 g.m $\mathrm{m}^{-2}$ (Table 2). Experimental coupons were cut from a larger sheet and were

$1595 \mathrm{~cm} \times 5 \mathrm{~cm}$ in size. They were cleaned using an aqueous slurry of $5 \mu \mathrm{m}$ polishing alumina,

160 rinsed with distilled water, degreased in hexane and allowed to air dry. All solvents and

161 reagents used were provided by the Sigma-Aldrich Chemical Company and of analytical 162 grade.

163 (Table 1)

164 (Table 2)

165 2.2 Methods

166 Materials Characterisation; A Hitachi TM3000 SEM with integrated Quantax 70 EDX

167 Analyser was used to obtain both SEM images of the various uncorroded ZAM 168 microstructure and images of the surface post-corrosion in HAc. PVB was mechanically 
169 peeled from the samples following removal from the humidity chamber. Any loose

170 corrosion product present was removed from the corroded samples during ultrasonication

171 in a non-polar hydrocarbon (hexane) for 10 minutes prior to SEM.

172 Filiform Corrosion; Insulating tape was applied to coupons in two parallel stripes. The tape

173 acted as a height guide onto which PVB was bar-cast before being allowed to dry in air (30

$174 \mu \mathrm{m}$ dry film thickness) $[22,23,28-29,33]$. A scalpel blade was used to create $10 \mathrm{~mm}$ long

175 linear scribe penetrative coating defects to which aliquots $(2 \mu \mathrm{L})$ of $1.5 \mathrm{~mol} . \mathrm{dm}^{-3} \mathrm{HAc}$

176 (pH 2) were applied using a micro-syringe. Coupons were then placed in an experimental

177 chamber within which the relative humidity (RH) was maintained at $93 \%$ using reservoirs

178 of saturated $\mathrm{Na}_{2} \mathrm{SO}_{4} 10 \mathrm{H}_{2} \mathrm{O}[22,23,28-29,33]$. The temperature was held constant at $25{ }^{\circ} \mathrm{C}$.

179 A Canon EOS was used to take digital optical images of the sample surface once per week,

180 at which point the chamber air was refreshed. Sigma Scan Pro 5 image analysis software

181 was used to take measurements from the images and obtain values of FFC corroded area.

182 Calibration of the image analysis software was completed by specifying a pre-measured

183 distance between two points in the image and inputting the real distance. Measurements of 184 corroded area were taken from four individual scribes (2 samples each with 2 scribes) for 185 each coating composition and coating weight.

\section{3. Results and Discussion}

\subsection{Materials Characterisation}

188 Figure 1 shows cross sections of the four 1.5Al- $1.5 \mathrm{Mg}$ coatings of varying coating weight.

189 The mean thickness of each coating was determined by taking several measurements across

190 the coating from five different images and are shown in Table 2. Zinc dendrites, binary and

191 ternary eutectic phases are present in all coatings at approximately equal proportions. 
192 Figure 2 shows SEM backscatter images of the surface of the four ZAM alloys before

193 immersion in HAc (0 hours). Each of the samples were supplied with similar ZAM coating

194 weights, giving a roughly constant thickness for each different composition. The area

195 percentage, along with the composition, of each phase present are shown in Table 3. Values

196 shown are based on measurements taken on five different areas. Both 1Al-1Mg (Figure 2a)

197 and $1.5 \mathrm{Al}-1.5 \mathrm{Mg}$ (Figure $2 \mathrm{~b}$ ) alloys coating consists of zinc dendrites (Zn HCP) within a

198 coarse binary eutectic phase and a finer ternary eutectic. The binary eutectic consists of

199 zinc and $\mathrm{MgZn}_{2}$ lamellae and the ternary eutectic consists of zinc, a zinc rich aluminium

200 fcc phase and $\operatorname{MgZn}_{2}[10,72]$. By comparing Figure 2a and Figure $2 \mathrm{~b}$ it can be seen that

201 increasing the alloying additions of magnesium and aluminium increases the proportion of

202 binary and ternary eutectic from $\sim 10 \%$ to $\sim 30 \%$ and from $\sim 10 \%$ to $\sim 40 \%$ respectively.

203 In comparison, the proportion of primary zinc dendrites decreases from $~ 80 \%$ to $30 \%$

204 and they become smaller in size $(\sim 50 \mu \mathrm{m}$ to $<10 \mu \mathrm{m})$. Figure $2 \mathrm{c}$ shows the surface of the

205 3Al-3Mg alloy. A fourth dendritic, zinc rich aluminium phase, ( $10 \%)$ forms from the

206 aluminium which has been excluded from the primary zinc dendrites during solidification.

207 The composition of this phase, as determined using EDX, (Table 3) is Al (21wt. \%) and

208 Zn (79 wt.\%) with very little magnesium. The phase identified is consistent with an fcc Zn-

209 rich ( 60-80 \%) Al phase observed in $\mathrm{Zn}-\mathrm{Al}-\mathrm{Mg}$ coatings using wavelength dispersive $\mathrm{x}-$

210 ray spectrometry [73]. Figure $2 \mathrm{~d}$ shows the surface of the $6 \mathrm{Al}-3 \mathrm{Mg}$ alloy. Virtually no

211 primary zinc is formed in the coating, which consists primarily of ternary eutectic $(\sim 70 \%)$

212 and binary eutectic ( $10 \%)$. This excess of aluminium, above that required for formation

213 of the ternary eutectic, means there is a significant increase in the amount of the fourth $\mathrm{Zn}$ -

214 Al phase to $20 \%$.

215 (Figure 1) 


\subsection{Post Corrosion Surface Characterisation}

219 The effect of differential aeration in FFC occurring on $1.5 \mathrm{Al}-1.5 \mathrm{Mg}$ has been found to be

220 reinforced by the preferential anodic dissolution of the magnesium-rich eutectic phases

221 which produces pathways in the ZAM coating to the iron substrate [18]. The exposed iron

222 is then able to galvanically couple to ZAM coating, increasing the driving force for filament

223 advance. It therefore seems reasonable to propose that a change in the exact composition

224 of the ZAM coating will affect the time to iron exposure and that FFC will be significantly

225 reduced in the case that exposure of the substrate is prolonged.

226 The effect of coating composition on both the ability of HAc to attack the ZAM coating

227 microstructure, and the time to iron exposure, was further investigated by immersing ZAM

228 coated coupons in 0.1 mol.dm ${ }^{-3}$ HAc. Samples were removed from the electrolyte hourly,

229 rinsed with distilled water and immersed in hexane for 5 minutes in an ultrasound bath to

230 mechanically remove corrosion products. Figure 2a shows backscatter SEM images, and

231 the corresponding EDS maps, of the $1 \mathrm{Al}-1 \mathrm{Mg}$ surface obtained after various times of

232 immersion. The change in wt. \% of each element with time, as measured using EDS, is

233 shown clearly for each coating type in Figure 3. The time dependent Mg wt. \% (Figure 3a)

234 follows a similar trend for each alloy; a sharp decrease followed by a plateau. The time

235 taken for the value to plateau increases from 1 hour in the case of $1 \mathrm{Al}-1 \mathrm{Mg}$, to

236 approximately 5 in the case of $6 \mathrm{Al}-3 \mathrm{Mg}$. An increase in $\mathrm{Al}$ (which does not dissolve in

237 HAc) occurs over the experimental time period as the surface becomes enriched. The time 238 taken for the value to plateau approximately doubles from 2 hours to $\sim 4$ hours for the $1 \mathrm{Al}$ - 
$2391 \mathrm{Mg}$ and $6 \mathrm{Al}-3 \mathrm{Mg}$ respectively. The Fe wt.\% (Figure 3c) increases sharply after a time

240 period, the length of which depends upon the initial amount of $\mathrm{Al}$ and $\mathrm{Mg}$ present within

241 the coating. For $1 \mathrm{Al}-1 \mathrm{Mg}$ coatings, the Fe content reaches 81.2 wt. \% after 3 hours of

242 immersion. In comparison the Fe content of the $1.5 \mathrm{Al}-1.5 \mathrm{Mg}$ coating is $4.1 \mathrm{wt}$. $\%$ after 3

243 hours and does not reach 82.2 wt. \% until after 4 hours of immersion. The corresponding

244 SEM and EDS images in Figure 2b show that iron is exposed more quickly in the eutectic

245 regions compared to regions in which zinc dendrites are present. The EDS maps for the

246 3Al- 3Mg (Figure 2c) and 6Al-3Mg (Figure 2d) coatings show that iron is exposed more

247 quickly in eutectic regions compared to those in which the $\mathrm{Zn}$ rich $\mathrm{Al}$ phase is present.

$248 \quad$ (Figure 3)

249 Figure 4 shows SEM images of the cross section of both a $1 \mathrm{Al}-1 \mathrm{Mg}$ and $6 \mathrm{Al}-3 \mathrm{Mg}$ coating

250 after 15 seconds immersed in 0.8 mol.dm ${ }^{-3}$ HAc. This experiment was conducted to

251 compare the dissolution rate of two coatings and a higher concentration of HAc was used

252 than during previous studies in order to reduce the experimental time. The images clearly

253 show the $1 \mathrm{Al}-1 \mathrm{Mg}$ coating almost entirely dissolves after 15 seconds and much of the iron

254 substrate is left exposed. In comparison, the undissolved coating forms a tortuous path to

255 the substrate in the case of the $6 \mathrm{Al}-3 \mathrm{Mg}$ coating.

\section{6 (Figure 4)}

257 The EDS technique used here is associated with an interaction volume and it is therefore 258 not clear whether the increase in Fe observed in Figure 3 results from the active exposure 259 of substrate Fe or that buried under residual $\mathrm{Zn}$ or corrosion product. However, what is 260 clear is that the degree to which the Fe substrate is covered decreases during immersion in 261 HAc, and from Figure 4 it is further evident that percolating pathways to the substrate 
262 would become open prior to complete removal of the ZAM coating. The presence of such

263 pathways allows the Fe surface to contribute to cathodic activity, this in turn increasing the

264 FFC propagation rate. Follow the immersion of coatings with increased Al content (Figure

$2654 \mathrm{~b})$ the extent of pathway formation is reduced, and it follows that the influence of the Fe

266 substrate in contributing to cathodic activity also decreases.

267 A similar study was completed to determine the effect of $1.5 \mathrm{Al}-1.5 \mathrm{Mg}$ coating weight 268 (thickness), on time to iron exposure. The ZAM coating weight (thickness) was 269 systematically changed from 70 g.m $\mathrm{m}^{-2}$ to 350 g.m $\mathrm{m}^{-2}$ and samples were immersed in 0.1

270 mol.dm ${ }^{-3}$ HAc. Figure 5 shows that the time to iron (substrate) exposure changes almost

271 linearly as a function of coating weight (thickness).

272 (Figure 5)

$273 \quad 3.3$ Filiform Corrosion Study

274 Effect of coating composition; A systematic study was conducted with the aim of 275 determining the effect of ZAM coating composition on the kinetics of FFC. In so doing $2762 \mu \mathrm{L}$ aliquots of $1.5 \mathrm{~mol} . \mathrm{dm}^{-3} \mathrm{HAc}$ (which has previously been shown to initiate FFC 277 quickly and reproducibly) [18] were injected into the scribed PVB coating defect. Figure 278 6a shows representative optical images of PVB coated 1.5Al-1.5Mg samples taken 1, 4 and 2798 weeks after injection of 1.5 mol.dm ${ }^{-3}$ HAc into a coating scribe. The FFC filaments 280 appear white against the dark substrate. FFC is observed in the first week following 281 initiation (Figure 6a) and filaments extend perpendicular to the direction of the scribe. As 282 time progresses these filaments propagate away from the defect and the FFC corroded area 283 increases considerably after 4 and 8 weeks. Similar images were acquired for each of the 284 ZAM coating compositions; $1.5 \mathrm{Al}-1.5 \mathrm{Mg}$ (Figure 6b), 3Al-3Mg (Figure 6c) and 6Al-3Mg 
285 (Figure 6d). There is a delay in FFC initiation on $1.5 \mathrm{Al}-1.5 \mathrm{Mg}$ and FFC is not observed

286 one week after initiation (Figure 6b). After 4 weeks FFC is observed and the FFC corroded

287 area has increased after 8 weeks. The delay in FFC initiation is prolonged on $3 \mathrm{Al}-3 \mathrm{Mg}$ and

288 FFC is not observed after 4 weeks (Figure 6c). Finally, in the case of 6Al-3Mg coatings

289 FFC is not observed over the entire 8-week period and the experimental time period was

290 extended to 20 weeks, after which FFC was still not observed.

291 (Figure 6)

292 The time dependent total corroded area on each type of sample was obtained by digital

293 image analysis of the whole filament population. Figure 7 and Table 4 show total corroded

294 area as a function of time for various ZAM coating compositions. For the sake of legibility,

295 the confidence intervals (which correspond to \pm one standard deviation on the mean of four

296 measurements) given in Table 4 are not reproduced in Figure 7. Linear extrapolation gives

297 a non-zero $\mathrm{x}$-axis intercept corresponding to a composition dependent initiation period

298 (delay). This initiation time increases from $\sim 2$ weeks for $1.5 \mathrm{Al}-1.5 \mathrm{Mg}$ to $\sim 3$ weeks for $3 \mathrm{Al}-$

$2993 \mathrm{Mg}$. Following initiation, total corroded area increases linearly with time and the mean

300 corroded area rate for each ZAM composition was obtained using linear regression (solid

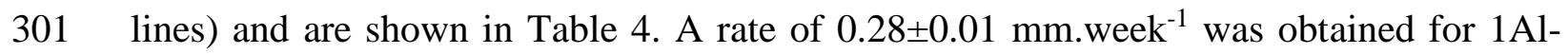

$3021 \mathrm{Mg}, 0.27 \pm 0.01 \mathrm{~mm}$. week $^{-1}$ for $1.5 \mathrm{Al}-1.5 \mathrm{Mg}, 0.10 \pm 0.01 \mathrm{~mm}$. week $^{1}$ for $3 \mathrm{Al}-3 \mathrm{Mg}$ and

$3030.05 \pm 0.01 \mathrm{~mm} . \mathrm{week}^{-1}$ for $6 \mathrm{Al}-3 \mathrm{Mg}$. The linearity of the area-time plots shown indicate

304 that FFC propagates at an approximately constant rate, this finding being consistent with

305 FFC in general and the notion that acetate (and therefore electrolyte volume) is conserved

306 in the propagating FFC head $[2,19-20]$. The fact that the kinetics are linear also implies

307 that the main cathodic site remains at a constant distance away from the leading anodic

308 head [28]. If this were not the case, and the cathodic site was constrained to the defect, then 
309 the rate of filament progression would be controlled by the migration of ions in the

310 underfilm electrolyte, and parabolic kinetics would become established. Linear kinetics are

311 observed in all cases, indicating that the rate limiting process does not change with

312 composition,

313 (Figure 7)

\section{4 (Table 4)}

315 Figure 8 and Table 5 show total corroded area as a function of time for $1.5 \mathrm{Al}-1.5 \mathrm{Mg}$ 316 coatings of varying coating weight (thickness). For coating weights of both $70 \mathrm{~g} \cdot \mathrm{m}^{-2}$ and

317100 g.m m $^{-2}$ FFC initiates within 1 week and proceeds to propagate at an approximately linear

318 rate. For coating weights of $140 \mathrm{~g} \cdot \mathrm{m}^{-2}$ FFC does not initiate for 2 weeks, this increasing to

3193 weeks in the case of the highest coating weight $\left(350 \mathrm{~g} \cdot \mathrm{m}^{-2}\right)$. The mean corroded area rate

320 for each coating weight was obtained using linear regression (solid lines) and are shown in

321 Table 5. A rate of $0.31 \pm 0.01 \mathrm{~mm} \cdot \mathrm{week}^{-1}$ was obtained for $70 \mathrm{~g} \cdot \mathrm{m}^{-2}$. Similar rates were

322 obtained for coatings of coating weight between 100 and $200 \mathrm{~g} . \mathrm{m}^{-2}$. For coating weights

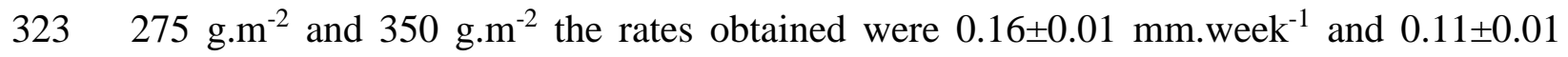

$324 \mathrm{~mm}$. week $^{1}$ respectively.

325 (Figure 8)

326 (Table 5)

327 In both Figure 7 and Figure 8 the initiation time (delay) is believed to correspond to a

328 process whereby the HAc initiant becomes converted to a metal acetate salt solution which

329 becomes the filament head electrolyte. Whilst it is likely that 1.) the FFC filament head 
330 HAc concentration is significantly lower than the 0.1 mol.dm ${ }^{-3} \mathrm{HAc}$ used during immersion

331 experiments (Figure 2) and that 2.) the acetate anions present will be associated with salts

332 of magnesium, zinc and aluminum, it is assumed that HAc induced FFC propagates via a

333 process of magnesium-rich ( $\mathrm{MgZn}_{2}$ in the eutectics) phase dissolution and iron exposure

334 [18]. The anodic attack of $\mathrm{MgZn}_{2}$ (at least initially) at the front of the filiform head could

335 then galvanically couple with cathodic ORR occurring either on zinc, or the iron substrate

336 (which will be exposed during dissolution of the coating), at the rear filament head. The

337 high solubility of magnesium acetate would ensure that it is retained within the advancing

338 electrolyte head. However the $\mathrm{Mg}^{2+}$ ions, which are released during the dissolution of $\mathrm{Mg}$

339 rich phases migrate toward the tail, can react with the $\mathrm{OH}^{-}$ions produced at the cathode to

340 form $\mathrm{Mg}(\mathrm{OH})_{2}$ once the solubility product $K s p\left(1.8 \times 10-11 \mathrm{~mol}^{3} \cdot \mathrm{dm}^{-9}\right)$ [74] is exceeded.

341 If FFC advancement were to proceed via this penetrative through coating mechanism, then

342 the linear relationship observed between coating thickness and time to iron exposure

343 (Figure 5) would be reflected by an inverse relationship between coating thickness and

344 FFC area rate (i.e. the increased charge required for dissolution of thicker coatings will

345 result in reduced rates of propagation). Indeed, Figure 9 shows an approximately linear

346 inverse relationship between the reciprocal of coating thickness and FFC corroded area rate.

\section{$347 \quad$ (Figure 9)}

348 With this in mind, it may be assumed that the relationship between iron exposure time and

349 coating composition (Figure 3 and Table 4) manifests in a correlation between coating 
350 composition and the FFC performance of coatings. That is to say, the superior resistance

351 to FFC, demonstrated by coatings with higher levels of $\mathrm{Al}$ (notably in the case that the $\mathrm{Mg}$

352 content is fixed at $3 \mathrm{wt} . \%$ ), correlates well with time to iron exposure. These findings are

353 consistent with the increased corrosion performance exhibited by Galfan coatings (5 wt.\%

$354 \mathrm{Al}$ ), compared to $\mathrm{Zn} \mathrm{HDG}$, when both were subject to $\mathrm{NaCl}$ and cyclic wet/dry conditions

355 within a laboratory, as well as after 5 years of exposure to marine environment [75].

356 Approximately half the amount of zinc was released from a pure zinc sheet compared to

357 Galfan [75]. The zinc and aluminium hyd(oxides) initially formed were shown to react to

358 form Hydrozincite $\left(\mathrm{Zn}_{5}\left(\mathrm{CO}_{3}\right)_{2}(\mathrm{OH})_{6}\right)$ and Hydrotalcite $\left(\mathrm{Zn}_{6} \mathrm{Al}_{2}(\mathrm{OH})_{16} \mathrm{CO}_{3} \cdot 4 \mathrm{H}_{2} \mathrm{O}\right)$ [75].

359 High chloride deposition rates resulted in the subsequent formation of hydroxychlorides,

360 Simonkolleite $\left(\mathrm{Zn}_{5}(\mathrm{OH})_{8} \mathrm{Cl}_{2} \cdot \mathrm{H}_{2} \mathrm{O}\right)$ on bare $\mathrm{Zn}$ metal, and $\mathrm{Zn}_{2} \mathrm{Al}(\mathrm{OH})_{6} \mathrm{Cl} \cdot 2 \mathrm{H}_{2} \mathrm{O}$ and/or

$361 \mathrm{Zn}_{5}(\mathrm{OH})_{8} \mathrm{Cl}_{2} \cdot \mathrm{H}_{2} \mathrm{O}$ on the $\mathrm{Zn}-\mathrm{Al}$ coatings [75]. The improved corrosion performance of

362 Galfan was attributed to the improved barrier properties of corrosion products formed in

363 chloride-rich environments, and $\mathrm{Zn}_{6} \mathrm{Al}_{2}(\mathrm{OH})_{16} \mathrm{CO}_{3} \cdot 4 \mathrm{H}_{2} \mathrm{O}$ was believed to govern the long-

364 term runoff rate of zinc from Galfan [75].

365 However, it should, at this point, be considered that the difference in Al content of the

366 coatings used during this work is often accompanied by a change in $\mathrm{Zn}$ and $\mathrm{Mg}$ wt.\%.

367 Therefore, although it is well possible that the effect of composition on FFC corroded area

368 is linked to the $\mathrm{Al}$ content, the only pair of samples with identical $\mathrm{Mg}$ content (and still

369 significantly different microstructure) are $3 \mathrm{Al}-3 \mathrm{Mg}$ and $6 \mathrm{Al}-3 \mathrm{Mg}$. In all other cases, both

$370 \mathrm{Al}$ and $\mathrm{Mg}$ concentrations, as well as the microstructure, change.

371 In summary, this work establishes that small variations in composition can have significant

372 effects on the susceptibility of ZAM to anodic mechanisms of organic coating failure. The

373 composition of such coatings should therefore be optimized to ensure that the benefits 
374 afforded by the addition of $\mathrm{Mg}[14,50,52,54-55,65]$, and $\mathrm{Al}$, allow for maximum

375 corrosion resistance in a range of different scenarios, including, as demonstrated here,

376 when the surface is coated with a protective organic layer. When considering inhibition of

377 FFC by $\mathrm{Al}$ additions in the coating layer, an "indirect" contribution arising from $\mathrm{Al}$ and

$378 \mathrm{Mg}$ ions inhibiting the ORR on exposed iron cannot be ruled out. A similar effect has been

379 observed at the cut edge of galvanized steel due to a direct modification of the iron oxide

380 by zinc cations, which is enhanced by magnesium cations and causes an inhibition of

381 oxygen reduction directly on the steel [76]. Nevertheless, the simplest explanation of the

382 effect is that it results "directly" from the insolubility of Al in aqueous HAc and the

383 microscopically observed resistance of Al-rich phases to the experimental FFC electrolyte.

384 With this in mind, it should also be remembered that such coatings can corrode via a variety

385 of mechanisms, most notably cut edge corrosion, and this (alongside factors such as

386 environmental conditions) should be considered during coating design.

\section{5. Conclusions}

388 This paper describes a systematic study into the effect of Zn-Al-Mg (ZAM) coating

389 thickness and composition on the mechanism and kinetics of filiform corrosion (FFC).

390 - For Zn-1.5 wt.\% Al- 1.5 wt.\% Mg coatings immersed in 0.1 mol.dm ${ }^{-3}$ acetic acid

391 (HAc) a linear trend was observed between thickness and time before exposure of 392 the underlying iron substrate.

- An inverse linear relationship was found to exist between Zn-1.5 wt.\% Al- 1.5 wt.\% $\mathrm{Mg}$ coating thickness and FFC propagation rate.

- These findings are consistent with the hypothesis that filiform advancement occurs via a penetrative through coating mechanism in which anodic dissolution of the $\mathrm{Mg}$ 
rich phases (primarily $\mathrm{MgZn}_{2}$ ) allows $\mathrm{O}_{2}$ percolation to $\mathrm{Fe}$ substrate, which acts as the FFC cathode. The exposed iron is then able to galvanically couple to the ZAM coating, increasing the driving force for filament advance. In the case of thicker coatings, the increased charge required for dissolution will result in reduced rates of propagation.

- For all ZAM coating compositions (1-6 wt. \% Al, 1-3 wt. \% Mg) EDS derived

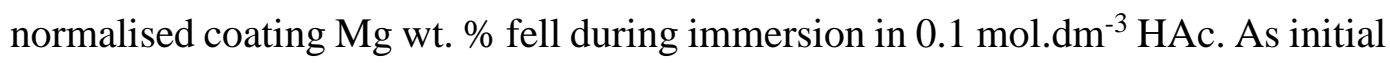
coating $\mathrm{Al}$ wt. \% was increased, the decrease in $\mathrm{Mg}$ wt. \%, and increase in substrate iron exposure (indicated by Fe wt. \%) occurred less rapidly.

- The decreased rate of FFC observed in the case of coatings with higher Al content is consistent with the hypothesis that FFC propagates via coating dissolution mechanism. It is believed that the presence of increased $\mathrm{Al}$ (which does not dissolve in HAc) creates a more torturous route to the iron substrate following dissolution of the $\mathrm{Mg}$ rich phases.

- Although HAc, known to initiate FFC, is ubiquitous within indoor environments, HAc induced FFC is yet to be observed on ZAM in service. It seems plausible that the exact composition of ZAM may be modified in such a way as to decrease the rate of FFC propagation in the case that it should occur.

\section{5. Acknowledgments}

416 The authors would like to thank Tata Steel for providing samples and EPSRC for the 417 funding for the Engineering Doctorate studentship via the Collaborate Training Account $418(\mathrm{GR} / \mathrm{T} 11333 / 01)$. 
as the data also forms part of an ongoing study.

421

422

423

424

425

426

427

428

429

430

431

432

433

434

435

436

437

438

439

440

441

442

443

444

445

446

447

448

449

450

451

452

453

454

455

\section{References}

1. D. Thierry, D. Persson, G. Luckeneder, K. H. Stellnberger, Atmospheric corrosion of $\mathrm{ZnAlMg}$ coated steel during long term atmospheric weathering at different worldwide exposure sites, Corrosion Science. 148 (2019) 338-354. https://doi.org/10.1016/j.corsci.2018.12.033.

2. G.Williams, H. N.McMurray, Underfilm/coating corrosion, in: B. R. A. Cottis,M. Graham, R. Lindsay, S. Lyon, T. J. A. Richardson, D. J. D. Scantlebury, H. Stott, (Eds.), Shreir's Corrosion, Elsevier Science, 2009, pp. .988-2004.

3. A. Leng, H. Streckel, M. Stratmann, The delamination of polymeric coatings from steel. Part 1: Calibration of the Kelvinprobe and basic delamination mechanism, Corrosion Science. 41 (1999) 547-578. https://doi.org/10.1016/S0010938X(98)00166-8.

4. A. Leng, H. Streckel, and M. Stratmann, The delamination of polymeric coatings from steel. Part 2: First stage of delamination, effect of type and concentration of cations on delamination, chemical analysis of the interface, Corrosion Science. 41 (1999) 579-597. https://doi.org/10.1016/S0010-938X(98)00167-X.

5. G. Williams, H.N. McMurray, Chromate Inhibition of Corrosion-Driven Organic Coating Delamination Studied Using a Scanning Kelvin Probe Technique, Journal of the Electrochemical Society. 148 (2001) B377-B385. https://doi.org/ doi:10.1149/1.1396336.

6. W. Furbeth, M. Stratmann, Investigation of the delamination of polymer films from galvanized steel with the Scanning Kelvinprobe, Fresenius' Journal of Analytical Chemistry. 353, 337 (1995) 337-341. https://doi.org/10.1007/BF00322064.

7. W. Furbeth, M. Stratmann, The delamination of polymeric coatings from electrogalvanised steel - a mechanistic approach.: Part 1: delamination from a defect with intact zinc layer, Corrosion Science. 43 (2001) 207-227. https://doi.org/10.1016/S0010-938X(00)00047-0.

8. W. Furbeth, M. Stratmann, The delamination of polymeric coatings from electrogalvanized steel - a mechanistic approach.: Part 2: delamination from a defect down to steel, Corrosion Science. 43 (2001) 229-241. https://doi.org/10.1016/S0010-938X(00)00048-2.

9. W. Furbeth, M. Stratmann, The delamination of polymeric coatings from electrogalvanized steel - a mechanistic approach.: Part 3: delamination kinetics and influence of CO2, Corrosion Science. $43 \quad$ (2001) 243-254. https://doi.org/10.1016/S0010-938X(00)00049-4. 
10. J. Sullivan, N. Cooze, C. Gallagher, T. Lewis, T. Prosek, D. Thierry, In situ monitoring of corrosion mechanisms and phosphate inhibitor surface deposition during corrosion of zinc-magnesium-aluminium (ZMA) alloys using novel timelapse microscopy, Faraday Discussions. 180 (2015) 361-379. https://doi.org/ 10.1039/C4FD00251B.

11. J.H. Sullivan, S. Mehraban, J. Elvins, In situ monitoring of the microstructural corrosion mechanisms of zinc-magnesium-aluminium alloys using time lapse microscopy,Corrosion $\quad$ Science. $53 \quad$ (2011) 2208-2215. https://doi.org/10.1016/j.corsci.2011.02.043.

12. M. Arndt, J. Duchoslav, H. Itani, G. Hesser, C.K. Riener, G. Angeli, K. Preis, D. Stifter, K. Hingerl, Nanoscale analysis of surface oxides on $\mathrm{ZnMgAl}$ hot-dip-coated steel sheets, Analytical and Bioanalytical Chemistry. 403 (2012) 651-661. https://doi.org/10.1007/s00216-011-5507-0.

13. C. Commenda, J. Pühringer, Microstructural characterization and quantification of $\mathrm{Zn}-\mathrm{Al}-\mathrm{Mg}$ surface coatings, Materials Characterization. 61 (2010) 943-951. https://doi.org/10.1016/j.matchar.2010.06.008.

14. R. Hausbrand, M. Stratmann, M. Rohwerder, Corrosion of zinc-magnesium coatings: Mechanism of paint delamination, Corrosion Science. 51 (2009) 21072114. https://doi.org/10.1016/j.corsci.2009.05.042.

15. R. Hausbrand, M. Stratmann, M. Rohwerder, The Physical Meaning of Electrode Potentials at Metal Surfaces and Polymer/Metal Interfaces: Consequences for Delamination Corrosion, Passivation, and Anodic Films, Journal of the Electrochemical $\quad$ Society. $155 \quad$ (2008) C379.https://doi.org/10.1149/1.2926589.17.

16. A. Vimalanandan, A. Bashir, M. Rohwerder, $\mathrm{Zn}-\mathrm{Mg}$ and $\mathrm{Zn}-\mathrm{Mg}-\mathrm{Al}$ alloys for improved corrosion protection of steel: Some new aspects, Materials and Corrosion. 65 (2014) 392-400. https://doi.org/10.1002/maco.201307586.

17. R. Hausbrand, M. Stratmann, M. Rohwerder, Delamination Resistant Zinc Alloys: Simple Concept and Results on the System Zinc-Magnesium, Steel Res. Int. 74 (2003) 453-458. https://doi.org/10.1002/srin.200300212.

18. N. Wint, D. Eaves, E. Michailidou, A. Bennett, J.R. Searle, G. Williams, H.N. McMurray, The kinetics and mechanism of filiform corrosion occurring on zincaluminium-magnesium coated steel, Corrosion Science. 158 (2019) 108073. https://doi.org/10.1016/j.corsci.2019.06.028.

19. A. Bautista, Filiform corrosion in polymer-coated metals, Progress in Organic Coatings. 28 (1996) 49-58. https://doi.org/10.1016/0300-9440(95)00555-2.

20. R. T. Ruggeri and T. R. Beck, An Analysis of Mass Transfer in Filiform Corrosion, Corrosion-NACE. 39 (1983) 452-465. https://doi.org/10.5006/1.3581907.

21. G. Grundmeier, W. Schmidt, and M. Stratmann, Corrosion protection by organic coatings: electrochemical mechanism and novel methods of investigation, 

4686(00)00348-0.

22. G. Williams, H.N. McMurray, The mechanism of group (I) chloride initiated filiform corrosion on iron, Electrochemistry Communications. 5 (2003) 871-877. https://doi.org/10.1016/j.elecom.2003.08.008.

23. T. M.Watson, A. J. Coleman, G.Williams, and H. N. McMurray, The effect of oxygen partial pressure on the filiform corrosion of organic coated iron, Corrosion Science. 89 (2014) 46-58. https://doi.org/10.1016/j.corsci.2014.08.004.

24. W.H. Slabaugh, M. Grotheer, Mechanism of Filiform Corrosion, Industrial \& Engineering Chemistry. $46 \quad$ (1954) 1014-1016. https://doi/pdf/10.1021/ie50533a053.

25. W. Schmidt and M. Stratmann, Scanning kelvinprobe investigations of filiform corrosion on aluminum alloy 2024-t3, Corrosion Science. 40 (1998) 1441-1443. https://doi.org/10.1016/S0010-938X(98)00044-4.

26. J. H. W. de Wit, New knowledge on localized corrosion obtained from local measuring techniques, Electrochimica Acta. 46 (2001) 3641-3650. https://doi.org/10.1016/S0013-4686(01)00642-9.

27. N. LeBozec, D. Persson, D. Thierry, S.B. Axelsen, Effect of Climatic Parameters on Filiform Corrosion of Coated Aluminum Alloys, CORROSION. 60 (2004) 584593. https://doi.org/10.5006/1.3287763.

28. G. Williams, H.N. McMurray, The Kinetics of Chloride-Induced Filiform Corrosion on Aluminum Alloy AA2024-T3, Journal of The Electrochemical Society. 150 (2003) B380-B388. https://doi:10.1149/1.1589020.

29. H.N. McMurray, G. Williams, S. O'Driscoll, Chromate Inhibition of Filiform Corrosion on Organic Coated AA2024-T3 Studied Using the Scanning Kelvin Probe, Journal of the Electrochemical Society. 151 (2004) B406-B414. https://doi.org/10.1149/1.1757460.

30. H.N. McMurray, A. Holder, G. Williams, G.M. Scamans, A.J. Coleman, The kinetics and mechanisms of filiform corrosion on aluminium alloy AA6111, $\begin{array}{lllll}\text { Electrochimica } & \text { Acta. } & 55 & \text { (2010) } & \text { 7843-7852. }\end{array}$ https://doi.org/10.1016/j.electacta.2010.04.035.

31. J.V. Kloet, W. Schmidt, A.W. Hassel, M. Stratmann, The role of chromate in filiform corrosion inhibition, Electrochimica Acta. 49 (2004) 1675-1685. https://doi.org/10.1016/S0013-4686(03)00256-1.

32. J.V. Kloet, W. Schmidt, A.W. Hassel, M. Stratmann, The role of chromate in filiform corrosion inhibition, Electrochimica Acta. 48 (2003) 1211-1222. https://doi.org/10.1016/S0013-4686(02)00829-0. 
33. G. Williams, R. Grace, Chloride-induced filiform corrosion of organic-coated magnesium, Electrochimica Acta. 56 (2011) 1894-1903. https://doi.org/10.1016/j.electacta.2010.09.005.

34. C. Leygraf, J. Hedberg, P. Qiu, H. Gil, J. Henriquez, C.M. Johnson, W.R. Whitney Award Lecture: Molecular In Situ Studies of Atmospheric Corrosion, CORROSION. 63 (2007) 715-721. https://doi.org/10.5006/1.3278420.

35. C.M. Johnson, E. Tyrode, C. Leygraf, Atmospheric Corrosion of Zinc by Organic Constituents: I. The Role of the Zinc/Water and Water/Air Interfaces Studied by Infrared Reflection/Absorption Spectroscopy and Vibrational Sum Frequency Spectroscopy, Journal of The Electrochemical Society. 153 (2006) B113-B120. https://doi.org/10.1149/1.2164788.

36. C.M. Johnson, C. Leygraf, Atmospheric Corrosion of Zinc by Organic Constituents: II. Reaction Routes for Zinc-Acetate Formation, Journal of The $\begin{array}{lllll}\text { Electrochemical } & \text { Society. } & 153 & \text { (2006) } & \text { B542-B546. }\end{array}$ https://doi.org/10.1149/1.2360740.

37. H. Gil, C. Leygraf, J. Tidblad, GILDES Model Simulations of the Atmospheric Corrosion of Zinc Induced by Low Concentrations of Carboxylic Acids, Journal of The Electrochemical Society. $159 \quad$ (2012) C123-C128. https://doi.org/10.1149/2.072203jes.

38. P. Qiu, D. Persson, C. Leygraf, Initial Atmospheric Corrosion of Zinc Induced by Carboxylic Acids: A Quantitative In Situ Study, Journal of The Electrochemical Society. 156 (2009) C441-C447. https://doi.org/10.1149/1.3240878.

39. J. Hedberg, S. Baldelli, C. Leygraf, E. Tyrode, Molecular Structural Information of the Atmospheric Corrosion of Zinc Studied by Vibrational Spectroscopy Techniques: I. Experimental Approach, Journal of The Electrochemical Society. 157 (2010) C357-C362. https://doi.org/10.1149/1.3479207.

40. J. Hedberg, S. Baldelli, C. Leygraf, Molecular Structural Information of the Atmospheric Corrosion of Zinc Studied by Vibrational Spectroscopy Techniques: II. Two and Three-Dimensional Growth of Reaction Products Induced by Formic and Acetic Acid, Journal of The Electrochemical Society. 157 (2010) C363-C373. https://doi.org/10.1149/1.3479255.

41. D. Persson, C. Leygraf, Metal Carboxylate Formation during Indoor Atmospheric Corrosion of $\mathrm{Cu}, \mathrm{Zn}$, and $\mathrm{Ni}$, Journal of The Electrochemical Society. 142 (1995) 1468-1477.https://doi.org/10.1149/1.2048598.

42. E. Johansson, C. Leygraf, B. Rendahl, Characterisation of corrosivity in indoor atmospheres with different metals and evaluation techniques, British Corrosion Journal. 33 (1998) 59-66. https://doi.org/10.1179/000705998798114769.

43. C. Vargel, Chapter F.6 - Carboxylic Acids and their Derivatives, in: C. Vargel (Ed), Corrosion of Aluminium, Elsevier, 2004, pp. 513-541. 
44. A. Apelblat, E. Manzurola, Solubilities of magnesium, calcium, barium, cobalt, nickel, copper, and zinc acetates in water from $\mathrm{T}=(278.15$ to 348.15$) \mathrm{K}$, The Journal of Chemical Thermodynamics. 31(1999) 1347-1357.

45. H. M. Leung, S. D. Pike, A. J. Clancy, H. Chun Yau, W. Jun Lee, K. L. Orchard, M. S. P. Shaffer, C. K. Williams, Layered zinc hydroxide monolayers by hydrolysis of organozincs, Chemical Science. 9 (2018) 2135-2146. https://doi.org/10.1039/C7SC04256F.

46. J. Elvins, J.A Spittle, J.H. Sullivan, D.A. Worsley, The effect of magnesium additions on the microstructure and cut edge corrosion resistance of zinc aluminium alloy galvanised steel, Corrosion Science. 50 (2008) 1650-1658. https://doi.org/10.1016/j.corsci.2008.02.005.

47. R. Krieg, A. Vimalanandan, M. Rohwerder, Corrosion of Zinc and Zn-Mg Alloys with Varying Microstructures and Magnesium Contents. Journal of the Electrochemical. Society. 161 (2014) C156.

48. J. Elvins, J. A. Spittle, D. A. Worsley, Microstructural changes in zinc aluminium alloy galvanising as a function of processing parameters and their influence on corrosion, Corrosion $\quad$ Science. $47 \quad$ (2005) 2740-2759. https://doi.org/10.1016/j.corsci.2004.11.011.

49. T. Prosek, J. Hagström, D. Persson, N. Fuertes, F. Lindberg, O. Chocholatý, C. Taxén, J. Šerák, D. Thierry, Effect of the microstructure of Zn-Al and Zn-Al-Mg model alloys on corrosion stability, Corrosion Science. 110 (2016) 71-81. https://doi.org/10.1016/j.corsci.2016.04.022.

50. P. Volovitch, T. N. Vu, C. Allely, A. A. Aal, K. Ogle, Understanding corrosion via corrosion product characterization: II. Role of alloying elements in improving the corrosion resistance of $\mathrm{Zn}-\mathrm{Al}-\mathrm{Mg}$ coatings on steel, Corrosion Science. 53 (2011) 2437-2445. https://doi.org/10.1016/j.corsci.2011.03.016.

51. X. Zhang, T. N. Vu, P. Volovitch, C. Leygraf, K. Ogle, I. Odnevall Wallinder, The initial release of zinc and aluminium from non-treated Galvalume and the formation of corrosion products in chloride containing media, Applied Surface Science. 258 (2012) 4351-4359. https://doi.org/10.1016/j.apsusc.2011.12.112.

52. J. Duchoslav, M. Arndt, R. Steinberger, T. Keppert, G. Luckeneder, K.H. Stellnberger, J. Hagler, C.K. Riener, G. Angeli, D. Stifter, Nanoscopic view on the initial stages of corrosion of hot dip galvanized $\mathrm{Zn}-\mathrm{Mg}-\mathrm{Al}$ coatings, Corrosion Science. 83 (2014) 327-334. https://doi.org/10.1016/j.corsci.2014.02.027.

53. T.N. Vu, P. Volovitch, K. Ogle, The effect of $\mathrm{pH}$ on the selective dissolution of $\mathrm{Zn}$ and Al from Zn-Al coatings on steel, Corrosion Science. 67 (2013) 42-29. https://doi.org/10.1016/j.corsci.2012.09.042.

54. M. Salgueiro Azevedo, C. Allely, K. Ogle, P. Volovitch, Corrosion mechanisms of $\mathrm{Zn}(\mathrm{Mg}, \mathrm{Al})$ coated steel: 2. The effect of $\mathrm{Mg}$ and $\mathrm{Al}$ alloying on the formation and 
properties of corrosion products in different electrolytes, Corrosion Science. 90, (2015) 482-490. https://doi.org/10.1016/j.corsci.2014.07.042.

613

614

615

616

617

618

619

620

621

622

623

624

625

626

627

628

629

630

631

632

633

634

635

636

637

638

639

640

641

642

643

644

645

646

647

648

649

55. T. Prosek, D. Persson, J. Stoulil, D. Thierry, Composition of corrosion products formed on $\mathrm{Zn}-\mathrm{Mg}, \mathrm{Zn}-\mathrm{Al}$ and $\mathrm{Zn}-\mathrm{Al}-\mathrm{Mg}$ coatings in model atmospheric conditions, Corrosion $\quad$ Science. $86 \quad$ (2014) 231-238. https://doi.org/10.1016/j.corsci.2014.05.016.

56. J.D. Yoo, P. Volovitch, A.A. Aal, C. Allely, K. Ogle, The effect of an artificially synthesized simonkolleite layer on the corrosion of electrogalvanized steel, Corrosion Science. 70 (2013) 1-10. https://doi.org/10.1016/j.corsci.2012.10.024.

57. P. Volovitch, M. Serdechnova, K. Ogle, Aqueous Corrosion of Mg-Al Binary Alloys: Roles of $\mathrm{Al}$ and $\mathrm{Mg}$, Corrosion. 68 (2012) 557-570. https://doi.org/10.5006/i0010-9312-68-6-557.

58. T. Lostak, A. Maljusch, B. Klink, S. Krebs, M. Kimpel, J. Flock, S. Schulz, W. Schuhmann, Zr-based conversion layer on Zn-Al-Mg alloy coated steel sheets: insights into the formation mechanism, Electrochimica Acta. 137 (2014) 65-74. https://doi.org/10.1016/j.electacta.2014.05.163.

59. B. Schuhmacher, C. Schwerdt, U. Seyfert, O. Zimmer, Innovative steel strip coatings by means of PVD in a continuous pilot line: process technology and coating development, Surface and Coatings Technology. 163. (2003) 703-709. https://doi.org/10.1016/S0257-8972(02)00660-6,

60. J.L. Davies, C.F. Glover, J. Van de Langkruis, E. Zoestbergen, G. Williams, The effect of $\mathrm{Mg}$ concentration on the resistance of PVD Zn-Mg coatings to corrosion driven organic coating delamination, Corrosion Science. 100 (2015) 607-618. https://doi.org/10.1016/j.corsci.2015.08.03.

61. J. Duchoslav, M. Arndt, T. Keppert, G. Luckeneder, D. Stifter, XPS investigation on the surface chemistry of corrosion products on $\mathrm{ZnMgAl}$-coated steel, Analytical and Bioanalytical Chemistry. $405 \quad$ (2013) 7133-7144. https://doi.org/10.1007/s00216-013-7099-3).

62. S. Schuerz, M. Fleischanderl, G. H. Luckeneder, K. Preis, T. Haunschmied, G. Mori, A.C. Kneissl, Corrosion behaviour of $\mathrm{Zn}-\mathrm{Al}-\mathrm{Mg}$ coated steel sheet in sodium chloride-containing environment, Corrosion Science. 51 (2009) 2355-2363. https://doi.org/10.1016/j.corsci.2009.06.019.

63. T. Prosek, N. Larche, M. Vlot, F. Goodwin, D. Thierry, Corrosion performance of $\mathrm{Zn}-\mathrm{Al}-\mathrm{Mg}$ coatings in open and confined zones in conditions simulating automotive applications, Materials and Corrosion. 61 (2010) 412-420. https://doi.org/10.1002/maco.200905425.

64. L. Jiang, M. Wolpers, P. Volovitch, K. Ogle, Activation and inhibition of $\mathrm{Zn}-\mathrm{Al}$ and $\mathrm{Zn}-\mathrm{Al}-\mathrm{Mg}$ coatings on steel by nitrate in phosphoric acid solution, Corrosion Science. 60 (2012) 256-264. https://doi.org/10.1016/j.corsci.2012.03.028. 
65. T. Prosek, A. Nazarov, U. Bexell, D. Thierry, J. Serak, Corrosion mechanism of model zinc-magnesium alloys in atmospheric conditions, Corrosion Science. 50 (2008) 2216-2231. https://doi.org/10.1016/j.corsci.2008.06.008.

66. E. Diler, S. Rioual, B. Lescop,D. Thierry, B. Rouvellou,Chemistry of corrosion products of $\mathrm{Zn}$ and $\mathrm{MgZn}$ pure phases under atmospheric conditions, Corrosion Science. 65 (2012) 178-186. https://doi.org/10.1016/j.corsci.2012.08.014.

67. B. Li, A. Dong, G. Zhu, S. Chu, H. Qian, C. Hu, B. Sun, J. Wang, Investigation of the corrosion behaviors of continuously hot-dip galvanizing $\mathrm{Zn}-\mathrm{Mg}$ coating,

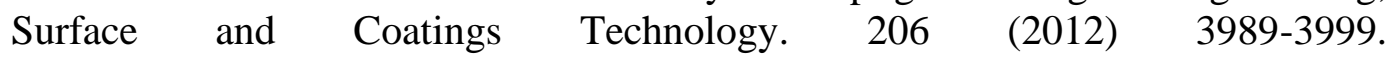
https://doi.org/10.1016/j.surfcoat.2012.03.079.

68. P. Volovitch, C. Allely, K. Ogle, Understanding corrosion via corrosion product characterization: I. Case study of the role of $\mathrm{Mg}$ alloying in $\mathrm{Zn}-\mathrm{Mg}$ coating on steel, $\begin{array}{llll}\text { Corrosion } & \text { Science. } & 51 & \text { (2009) }\end{array}$ https://doi.org/10.1016/j.corsci.2009.03.005.

69. N. C. Hosking, M. A. Ström, P. H. Shipway, C. D. Rudd, Corrosion resistance of zinc-magnesium coated steel, Corrosion Science. 49 (2007) 3669-3695. https://doi.org/10.1016/j.corsci.2007.03.032.

70. P. Volovitch, T.N. Vu, C. Allély, A. Abdel Aal, K. Ogle, Understanding corrosion via corrosion product characterization: II. Role of alloying elements in improving the corrosion resistance of $\mathrm{Zn}-\mathrm{Al}-\mathrm{Mg}$ coatings on steel, Corrosion Science. 51 (2009) 2355-2363. https://doi.org/10.1016/j.corsci.2009.06.019.

71. N. LeBozec, D. Thierry, A. Peltola, L. Luxem, G. Luckeneder, G. Marchiaro, M. Rohwerder, Corrosion performance of $\mathrm{Zn}-\mathrm{Mg}-\mathrm{Al}$ coated steel in accelerated corrosion tests used in the automotive industry and field exposures, Materials and Corrosion. 64 (2013) 969-978. https://doi.org/10.1002/maco.201206959.

72. E. De Bruycker, Z. Zermout, B. C. De Cooman, Zn-Al-Mg Coatings: Thermodynamic Analysis and Microstructure Related Properties, Materials Science $\quad$ Forum. 539-543 (2007) 1276-1281. https://10.4028/www.scientific.net/MSF.

73. M. Vlot, M. Juijderwijk, M. Toose, L. Elliot, R. Bleeker, T. Maalman, Hot dip ZnAlMg coatings: Microstructure and forming properties, Galvatech $7^{\text {th }}$ International Conference on Zinc and Zinc Alloy Coated Steel Sheet. (2007) 574579.

74. C. F. Baes, R. E. Mesmer, The Hydrolysis of Cations, Wiley, New York (1976).

75. X. Zhang, C. Leygraf, I. O. Wallinder, Atmospheric corrosion of Galfan coatings on steel in chloride-rich environments, Corrosion Science. 73 (2013) 62-71.

76. R. Krieg, M. Rohwerder, S. Evers, B. Schuhmacher, J. Schauer-Pass, Cathodic selfhealing at cut-edges: The effect of $\mathrm{Zn} 2+$ and $\mathrm{Mg} 2+$ ions, Corrosion Science. 65 (2012) 119-127. https://doi.org/10.1016/j.corsci.2012.08.008 
690 Figure 1. SEM backscatter images of the cross section of $1.5 \mathrm{Al}-1.5 \mathrm{Mg}$ coatings of various 691 coating weights a.) 70 g.m $\mathrm{m}^{-2}$, b.) 100 g.m $\mathrm{m}^{-2}$, c.) 140 g. $\mathrm{m}^{-2}$ d.) 200 g.m $\mathrm{m}^{-2}$, e.) 275 g.m $\mathrm{m}^{-2}$ and f.) $692350 \mathrm{~g} \cdot \mathrm{m}^{-2}$.

693 Figure 2. SEM backscatter images of the surface of a.) $1 \mathrm{Al}-1 \mathrm{Mg}$, b.) $1.5 \mathrm{Al}-1.5 \mathrm{Mg} \mathrm{c}$.) $3 \mathrm{Al}-$ $6943 \mathrm{Mg}$ and d.) $6 \mathrm{Al}-3 \mathrm{Mg}$ coatings alongside corresponding EDS elemental (Fe) maps 695 obtained after various times of immersion in 0.1 mol.dm ${ }^{-3}$ HAc.

696 Figure 3. Normalised a.) Mg wt.\%, b.) Al wt.\% and c.) Fe wt.\% obtained using EDS for 697 ZAM coatings of various compositions after various times of immersion in $0.1 \mathrm{~mol}^{-\mathrm{dm}^{-3}}$ 698 HAc.

699 Figure 4. a.) Backscatter SEM images of both a $1 \mathrm{Al}-1 \mathrm{Mg}$ and $6 \mathrm{Al}-3 \mathrm{Mg}$ cross section 700 obtained prior to and after 15 seconds immersed in 0.8 mol.dm ${ }^{-3} \mathrm{HAc}$.

701 Figure 5. Time to iron substrate exposure when $1.5 \mathrm{Al}-1.5 \mathrm{Mg}$ coatings of varying 702

703 Figure 6. Optical images of FFC propagating on a.) $1 \mathrm{Al}-1 \mathrm{Mg}$, b.) $1.5 \mathrm{Al}-1.5 \mathrm{Mg}$ c.) $3 \mathrm{Al}-$ $7043 \mathrm{Mg}$ and d.) $6 \mathrm{Al}-3 \mathrm{Mg}$ coated steel after 1 week, 4 weeks and 8 weeks after FFC has been 705 initiated by injecting $2 \mu \mathrm{L}$ of 1.5 mol.dm ${ }^{-3} \mathrm{HAc}$ to a scribe defect.

706 Figure 7. The time dependent corroded area for the case that FFC is initiated on ZAM 707 coatings of varying composition using $1.5 \mathrm{~mol} . \mathrm{dm}^{-3} \mathrm{HAc}$.

$7091.5 \mathrm{Mg}$ coatings of varying thickness using $1.5 \mathrm{~mol} . \mathrm{dm}^{-3} \mathrm{HAc}$.

710 Figure 9. FFC corroded area rate as a function of the reciprocal of $1.5 \mathrm{Al}-1.5 \mathrm{Mg}$ coating 711 thickness.

\section{8. Tables}

713 Table 1. List of ZAM coatings used during systematic study of the effect of coating 714 composition on susceptibility to FFC. Coating weight 140 g.m ${ }^{-2}$, coating thickness $\sim 10$ $715 \mu \mathrm{m}$.

\begin{tabular}{|c|c|c|c|}
\hline Denomination & Zinc (wt. \%) & Aluminium (wt. \%) & Magnesium (wt. \%) \\
\hline $\mathrm{A} 11-\mathrm{Mg} 1$ & 98 & 1 & 1 \\
\hline $\mathrm{A} 11.5-\mathrm{Mg} 1.5$ & 97 & 1.5 & 1.5 \\
\hline $\mathrm{Al} 3-\mathrm{Mg} 3$ & 94 & 3 & 3 \\
\hline $\mathrm{A} 16-\mathrm{Mg} 3$ & 91 & 6 & 3 \\
\hline
\end{tabular}

716 Table 2. List of ZAM (1.5Al-1.5Mg) coatings used during systematic study of the effect 717 of coating weight (thickness) on susceptibility to FFC. 


\begin{tabular}{|c|c|}
\hline Coating weight $\left(\mathbf{g . m}^{-\mathbf{2}}\right)$ & Coating thickness $(\boldsymbol{\mu m})$ \\
\hline 70 & 5 \\
\hline 100 & 7 \\
\hline 140 & 10 \\
\hline 200 & 14 \\
\hline 275 & 20 \\
\hline 350 & 27 \\
\hline
\end{tabular}

718 Table 3. SEM derived percentage of surface area covered by each phase present in each

719 coating and EDS derived phase compositions.

\begin{tabular}{|c|l|c|c|c|c|}
\hline Coating & \multicolumn{1}{|c|}{ Phase } & $\begin{array}{c}\text { Surface Area } \\
\text { Percentage }\end{array}$ & $\begin{array}{c}\text { Zn wt } \\
\text { \% }\end{array}$ & $\begin{array}{c}\text { Al wt. } \\
\%\end{array}$ & $\begin{array}{c}\text { Mg wt. } \\
\text { \% }\end{array}$ \\
\hline $1 \mathrm{Al}-1 \mathrm{Mg}$ & Primary Zinc & 80 & 99.7 & 0.2 & 0.1 \\
\hline & Binary eutectic & 10 & 95.9 & 0.5 & 3.6 \\
\hline & Ternary eutectic & 10 & 91.9 & 4.0 & 4.1 \\
\hline & Zn-Al & 0 & $/$ & $/$ & $/$ \\
\hline $1.5 \mathrm{Al}-1.5 \mathrm{Mg}$ & Primary Zinc & 30 & 99.6 & 0.0 & 0.3 \\
\hline & Binary eutectic & 30 & 95.1 & 0.7 & 4.2 \\
\hline & Ternary eutectic & 40 & 90.6 & 4.0 & 4.4 \\
\hline & Zn-Al & 0 & $/$ & $/$ & $/$ \\
\hline $3 \mathrm{Al}-3 \mathrm{Mg}$ & Primary Zinc & 10 & 99.5 & 0.1 & 0.5 \\
\hline & Binary eutectic & 30 & 94.8 & 0.5 & 4.7 \\
\hline & Ternary eutectic & 50 & 89.8 & 7.4 & 3.8 \\
\hline & Zn-Al & 10 & 80.6 & 19.3 & 0.1 \\
\hline $6 \mathrm{Al}-3 \mathrm{Mg}$ & Primary Zinc & 0 & $/$ & $/$ & $/$ \\
\hline & Binary eutectic & 10 & 95.4 & 0.5 & 4.1 \\
\hline & Ternary eutectic & 70 & 89.7 & 3.9 & 6.4 \\
\hline & Zn-Al & 20 & 79.2 & 21.7 & 0.0 \\
\hline
\end{tabular}

720 Table 4. Average corroded area in the case that FFC is initiated using $1.5 \mathrm{~mol}_{\mathrm{dm}} \mathrm{dm}^{-3} \mathrm{HAc}$

721 on varying compositions of ZAM coatings, along with corroded area rate.

\begin{tabular}{|c|c|c|c|c|}
\hline Time (weeks) & \multicolumn{4}{|c|}{ Area $\left(\mathrm{mm}^{2}\right)$} \\
\hline & 1Al-1Mg & $1.5 \mathrm{Al}-1.5 \mathrm{Mg}$ & 3Al-3Mg & 6Al-3Mg \\
\hline 0 & 0 & 0 & 0 & 0 \\
\hline 1 & $0.32 \pm 0.13$ & $0.10 \pm 0.03$ & $0.05+0.03$ & $0.01 \pm 0.01$ \\
\hline 2 & $0.51 \pm 0.19$ & $0.16 \pm 0.07$ & $0.08 \pm 0.04$ & $0.02 \pm 0.01$ \\
\hline 3 & $0.83 \pm 0.31$ & $0.41 \pm 0.24$ & $0.09 \pm 0.05$ & $0.02 \pm 0.01$ \\
\hline 4 & $1.13 \pm 0.45$ & $0.66 \pm 0.32$ & $0.17 \pm 0.14$ & $0.02 \pm 0.02$ \\
\hline 5 & $1.36 \pm 0.50$ & $0.96 \pm 0.44$ & $0.28 \pm 0.30$ & $0.03 \pm 0.01$ \\
\hline $\begin{array}{c}\text { Area rate } \\
\left(\mathrm{mm}^{2} . \text { week }^{-1}\right)\end{array}$ & $0.28 \pm 0.01$ & $0.27 \pm 0.01$ & $0.10 \pm 0.01$ & $0.05 \pm 0.01$ \\
\hline
\end{tabular}

722 Table 5. Average corroded area in the case that FFC is initiated using 1.5 mol.dm ${ }^{-3}$ HAc

723 on $1.5 \mathrm{Al}-1.5 \mathrm{Mg}$ ZAM coatings of varying thickness, along with corroded area rate. 


\begin{tabular}{|c|c|c|c|c|c|c|}
\hline & 70 g.m ${ }^{-2}$ & 100 g.m $\mathrm{m}^{-2}$ & 140 g.m ${ }^{-2}$ & 200 g.m ${ }^{-2}$ & 275 g.m ${ }^{-2}$ & 350 g.m ${ }^{-2}$ \\
\hline & $5 \mu \mathrm{m}$ & $7 \mu \mathrm{m}$ & $10 \mu \mathrm{m}$ & $14 \mu \mathrm{m}$ & $20 \mu \mathrm{m}$ & $27 \mu \mathrm{m}$ \\
\hline 0 & 0 & 0 & 0 & 0 & 0 & 0 \\
\hline 1 & $0.20 \pm 0.08$ & $0.15 \pm 0.08$ & $0.10 \pm 0.03$ & $0.03 \pm 0.02$ & $0.03 \pm 0.01$ & $0.02 \pm 0.01$ \\
\hline 2 & $0.56 \pm 0.25$ & $0.38 \pm 0.09$ & $0.16 \pm 0.07$ & $0.07 \pm 0.05$ & $0.08 \pm 0.03$ & $0.03 \pm 0.02$ \\
\hline 3 & $0.82 \pm 0.27$ & $0.62 \pm 0.15$ & $0.41 \pm 0.24$ & $0.21 \pm 0.18$ & $0.16 \pm 0.09$ & $0.04 \pm 0.02$ \\
\hline 4 & $1.20 \pm 0.43$ & $0.93 \pm 0.23$ & $0.66 \pm 0.32$ & $0.43 \pm 0.30$ & $0.33 \pm 0.14$ & $0.12 \pm 0.10$ \\
\hline 5 & $1.54 \pm 0.54$ & $1.19 \pm 0.34$ & $0.96 \pm 0.44$ & $0.76 \pm 0.47$ & $0.48 \pm 0.23$ & $0.25 \pm 0.12$ \\
\hline $\begin{array}{c}\text { Area rate } \\
\left(\mathrm{mm}^{2} \cdot \text { week }^{-1}\right)\end{array}$ & $0.31 \pm 0.01$ & $0.24 \pm 0.01$ & $0.27 \pm 0.01$ & $0.23 \pm 0.02$ & $0.16 \pm 0.01$ & $0.11 \pm 0.01$ \\
\hline
\end{tabular}




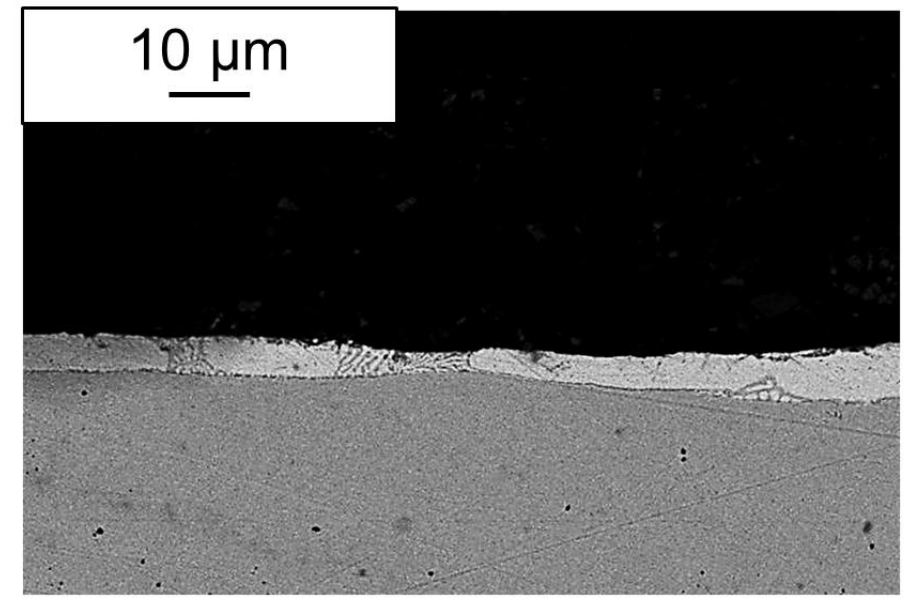

a.) $\quad 70 \mathrm{~g} \cdot \mathrm{m}^{-2}$

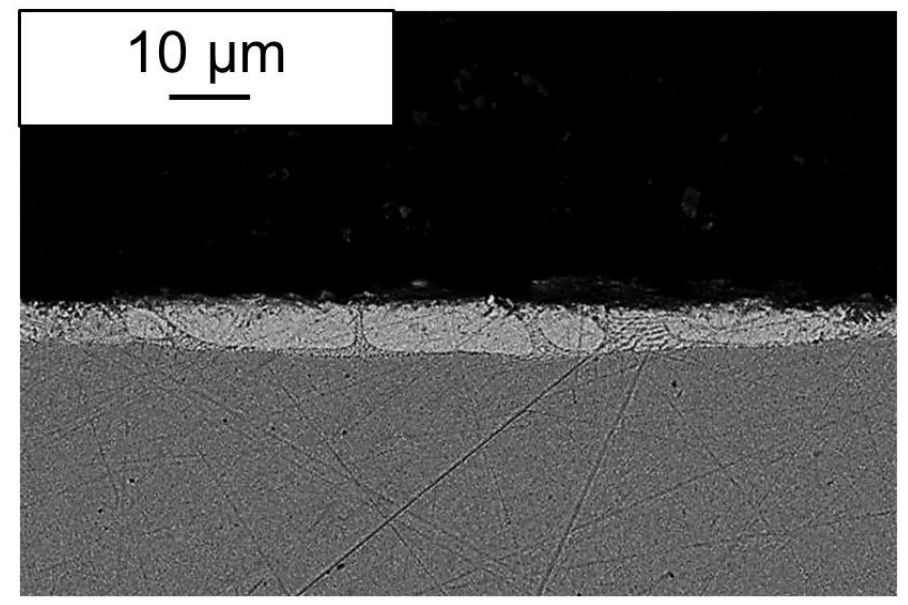

b.) $\quad 100 \mathrm{~g} \cdot \mathrm{m}^{-2}$

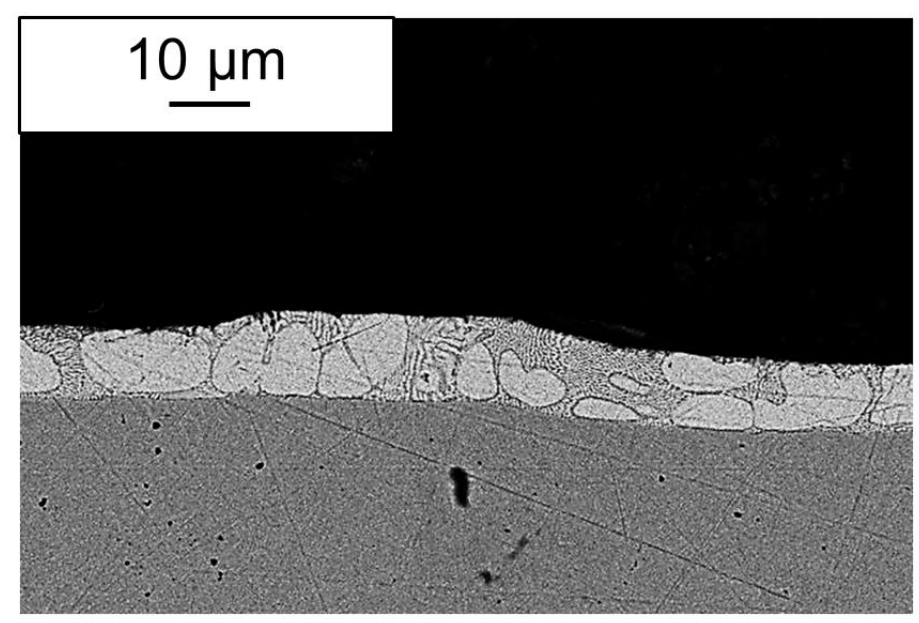

c.) $\quad 140 \mathrm{~g} \cdot \mathrm{m}^{-2}$

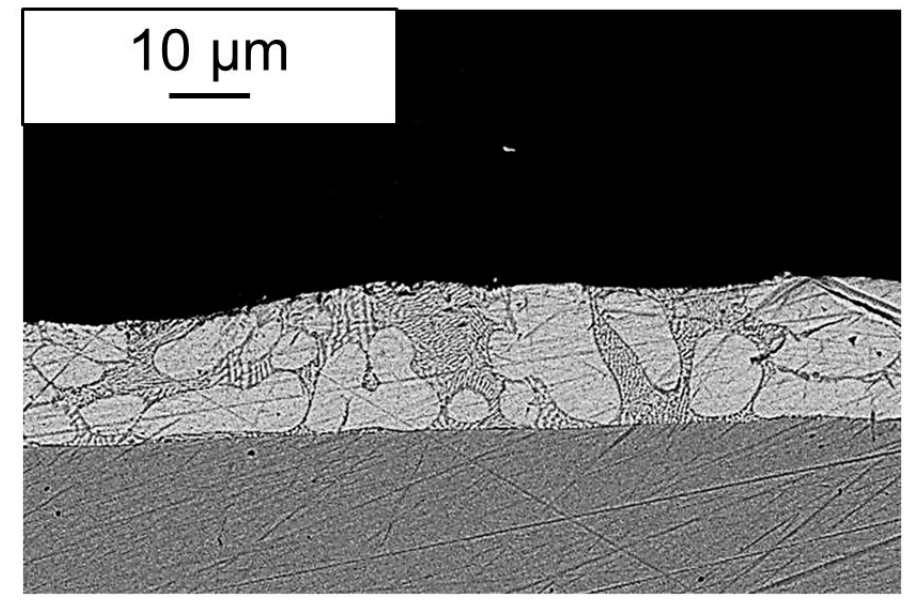

d.) $\quad 200 \mathrm{~g} \cdot \mathrm{m}^{-2}$

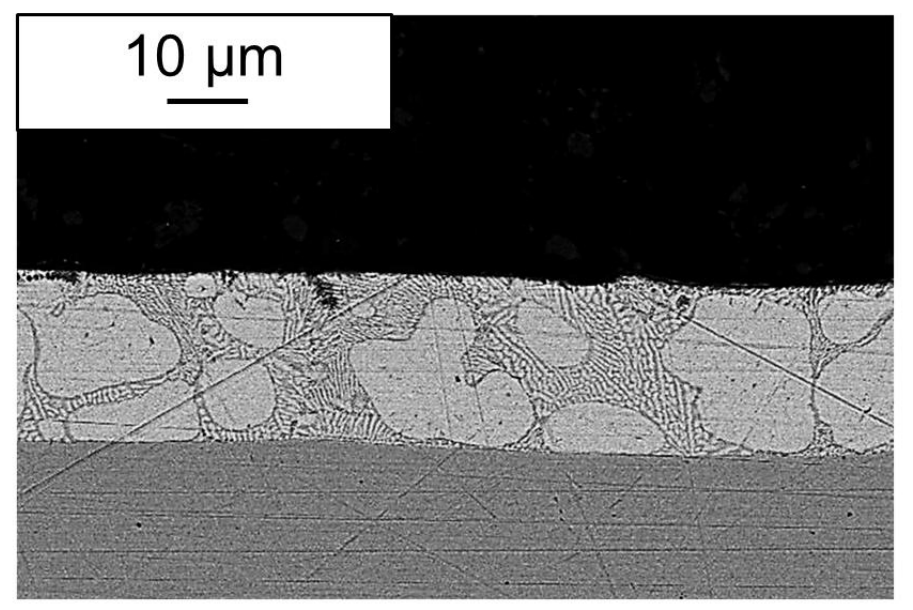
e.)
$275 \mathrm{~g} \cdot \mathrm{m}^{-2}$

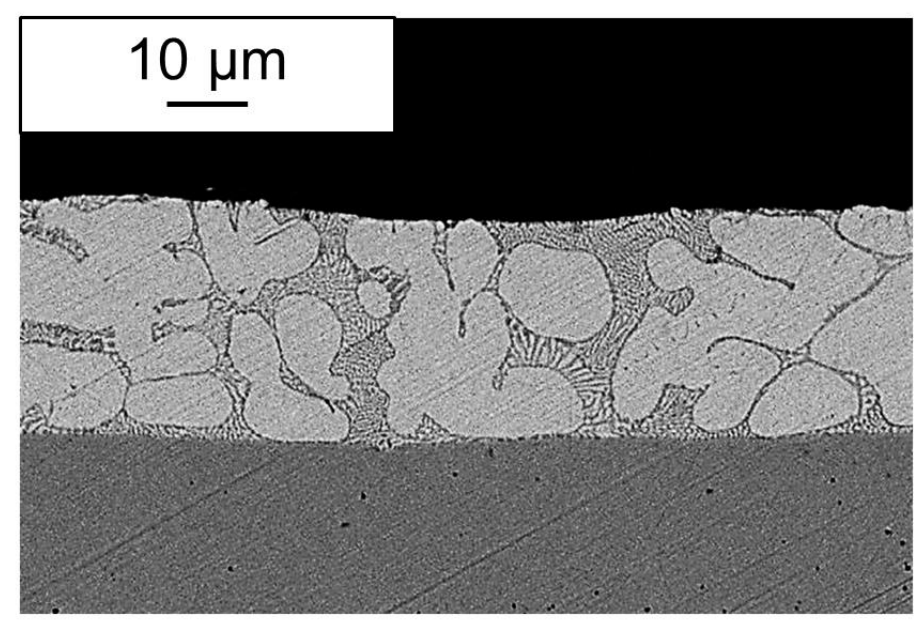

f.) $\quad 350 \mathrm{~g} \cdot \mathrm{m}^{-2}$ 


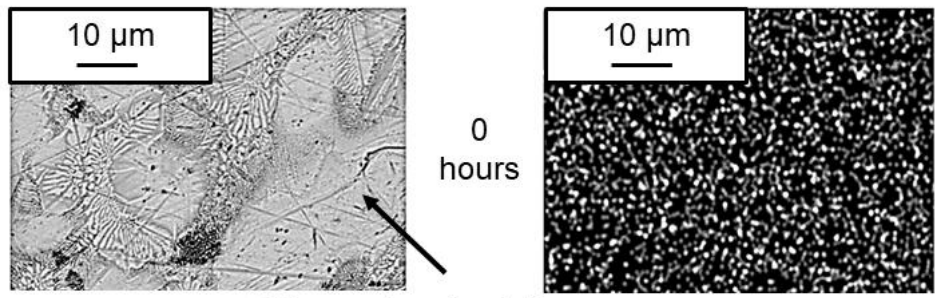

Primary zinc dendrite
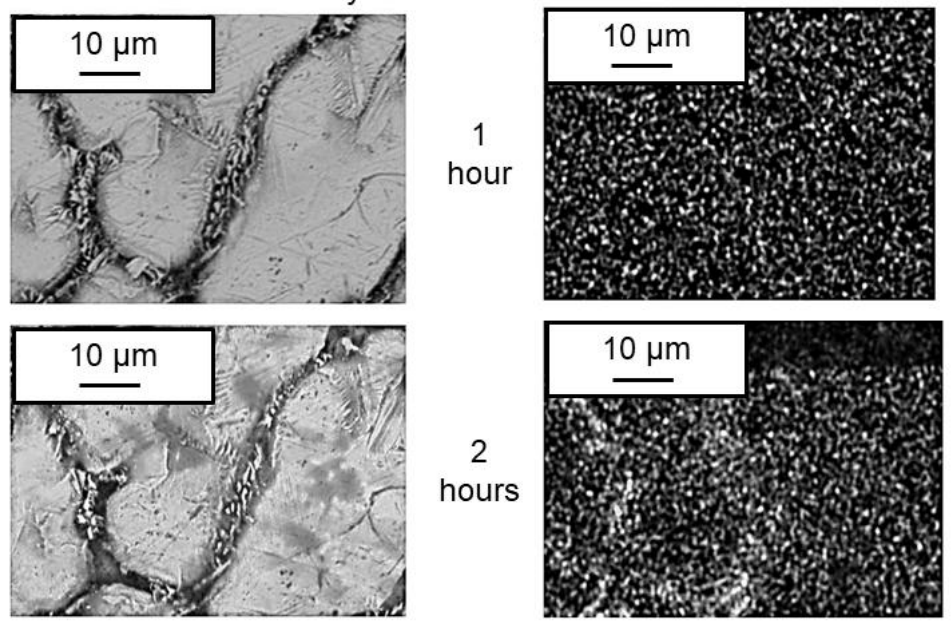

a.) $1 \mathrm{Al}-1 \mathrm{Mg}$
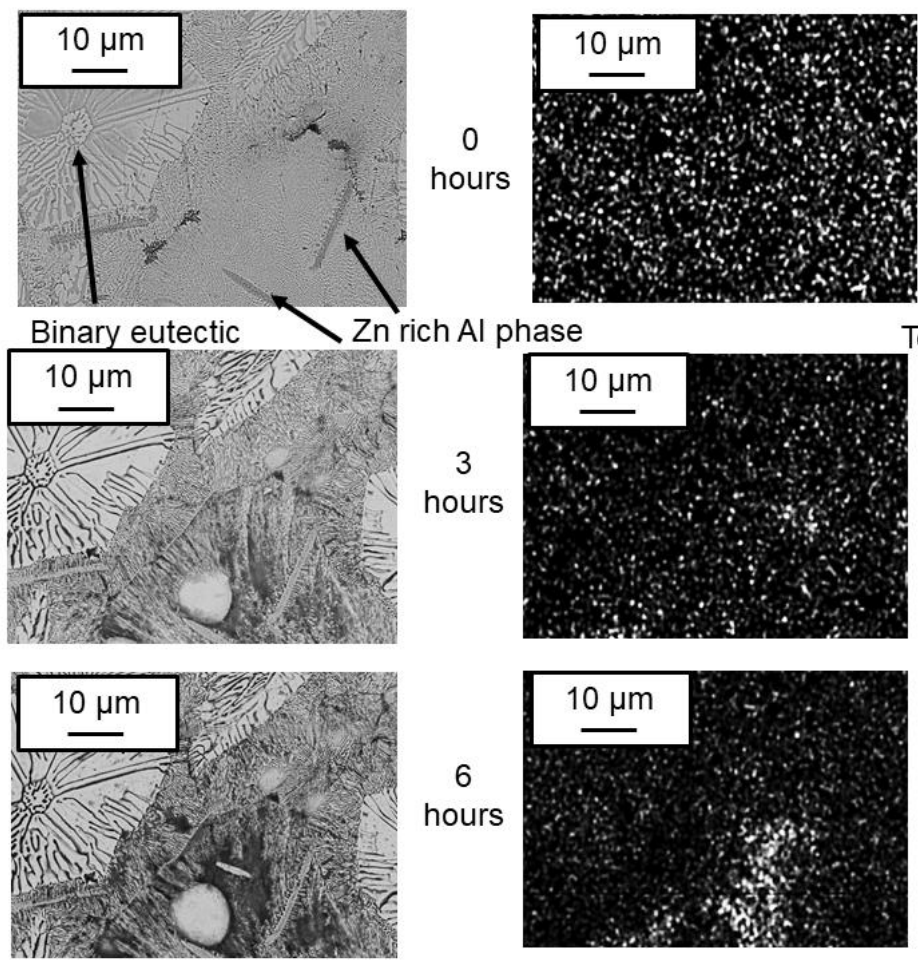

c.) $3 \mathrm{Al}-3 \mathrm{Mg}$
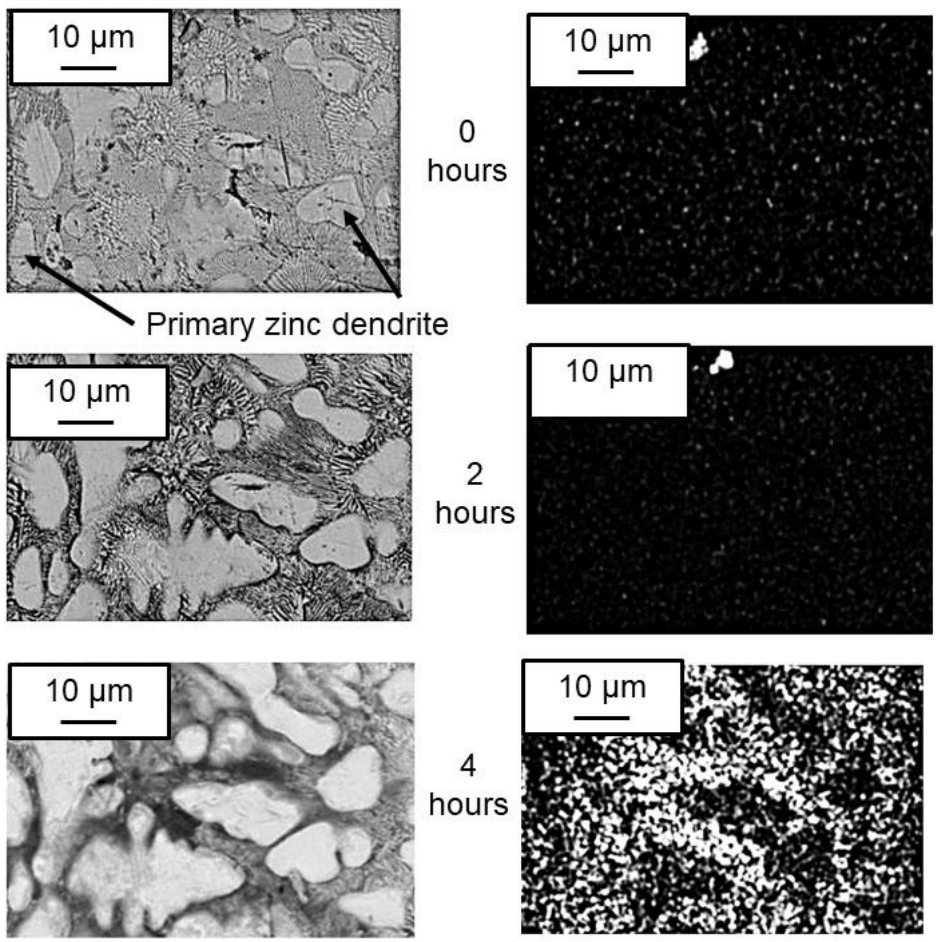

b.) $1.5 \mathrm{Al}-1.5 \mathrm{Mg}$

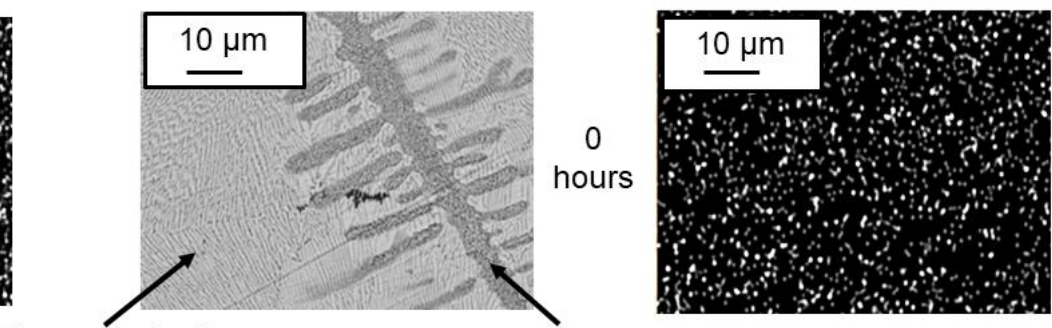
Ternary eutectic Zn rich Al phase
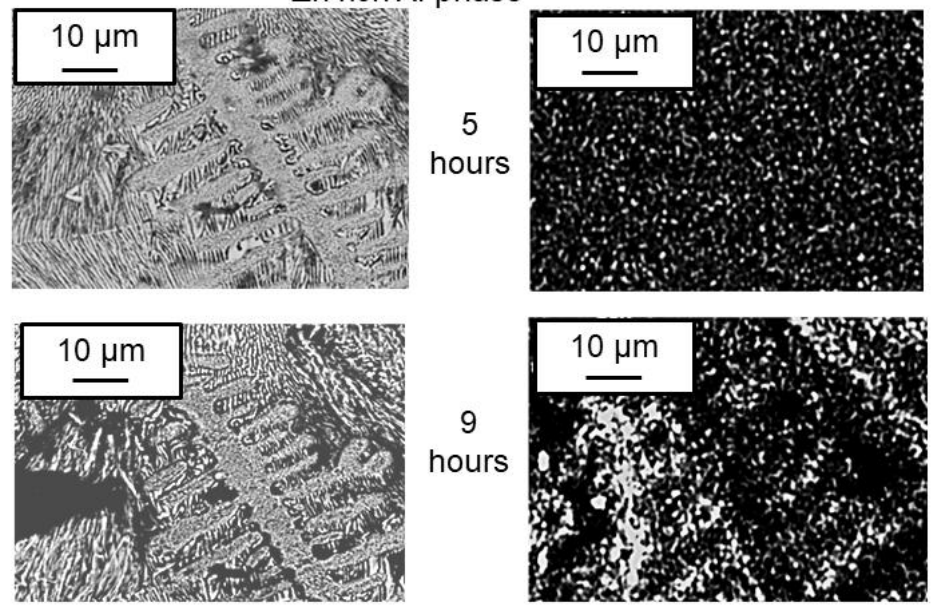

d.) $6 \mathrm{Al}-3 \mathrm{Mg}$ 

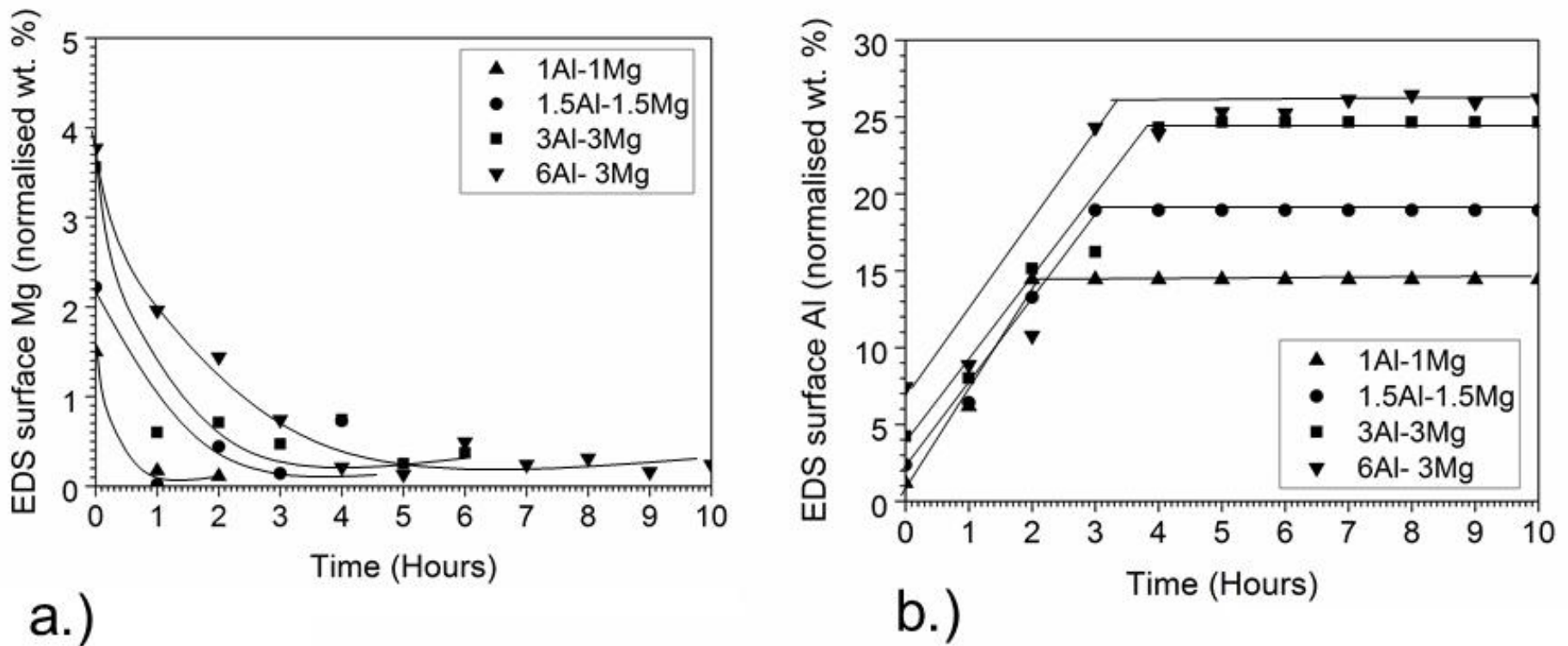

a.)

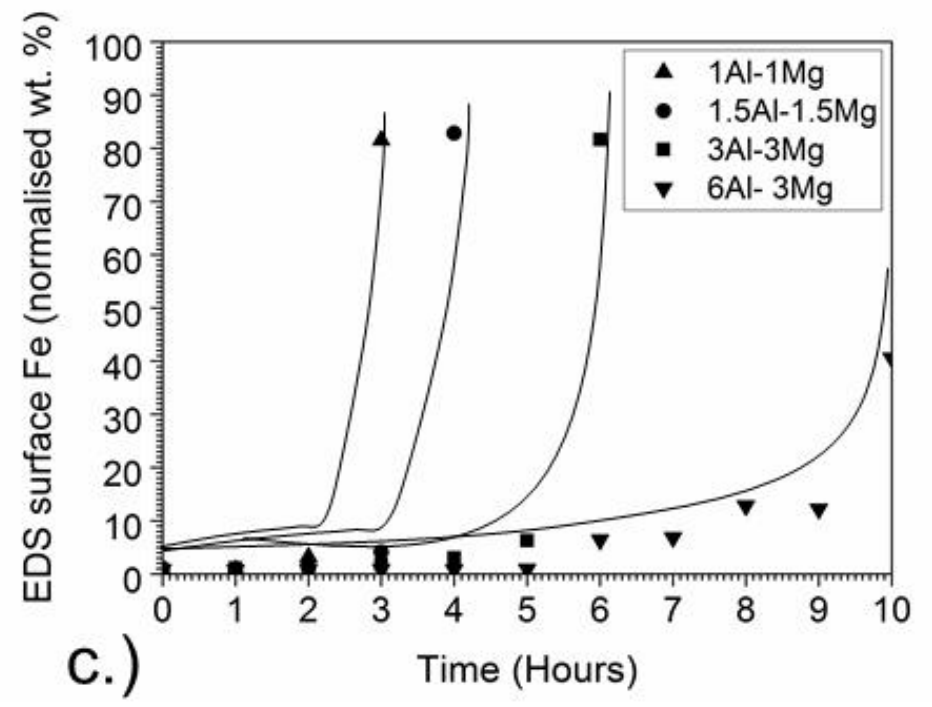




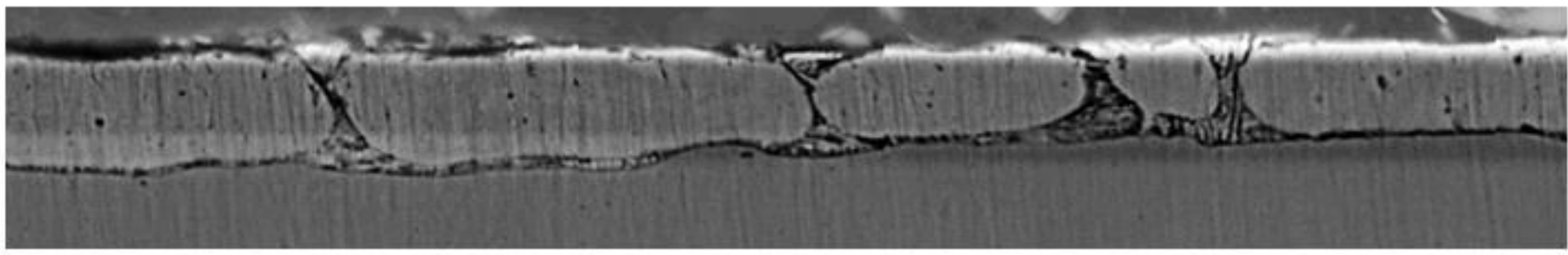

\section{0 seconds}
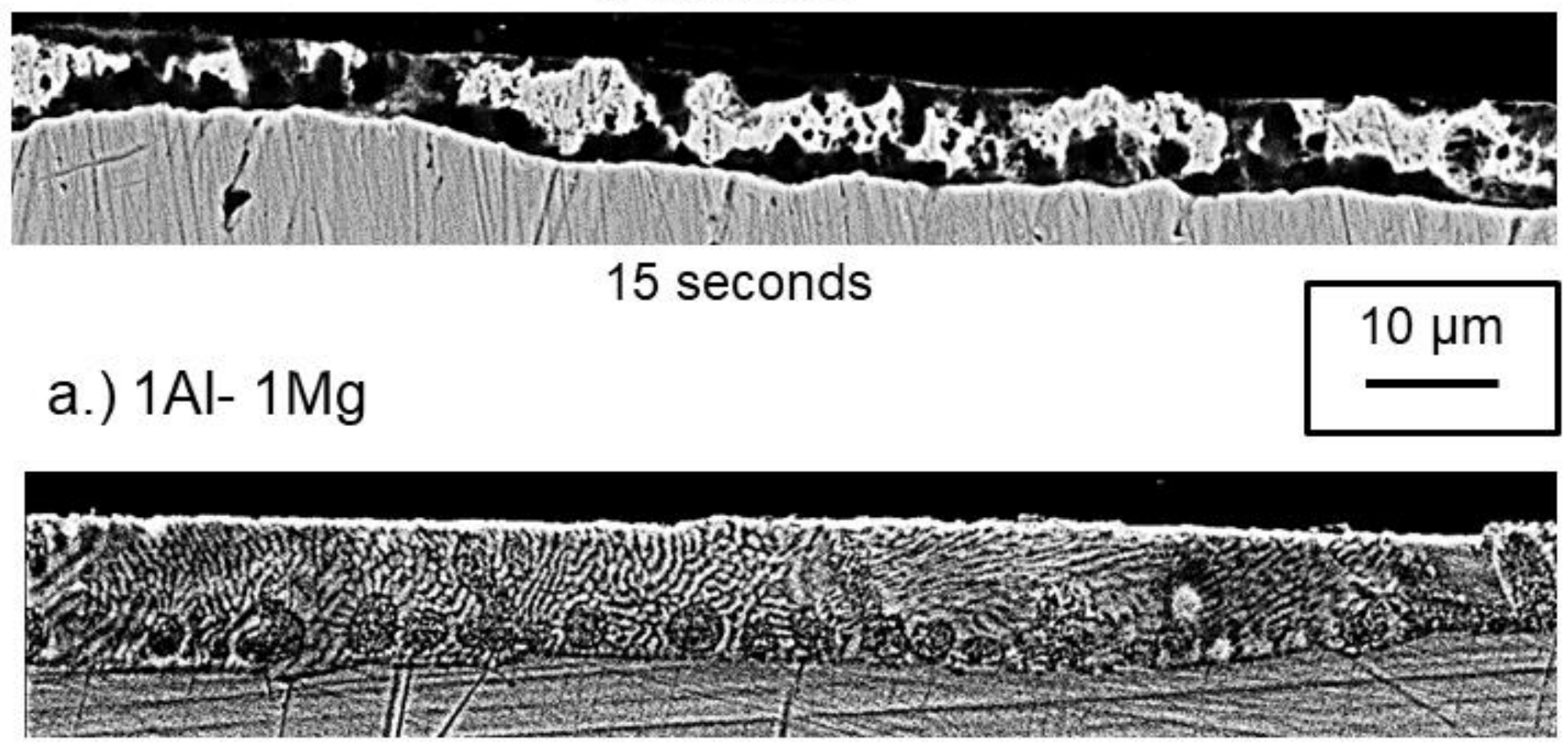

\section{0 seconds}

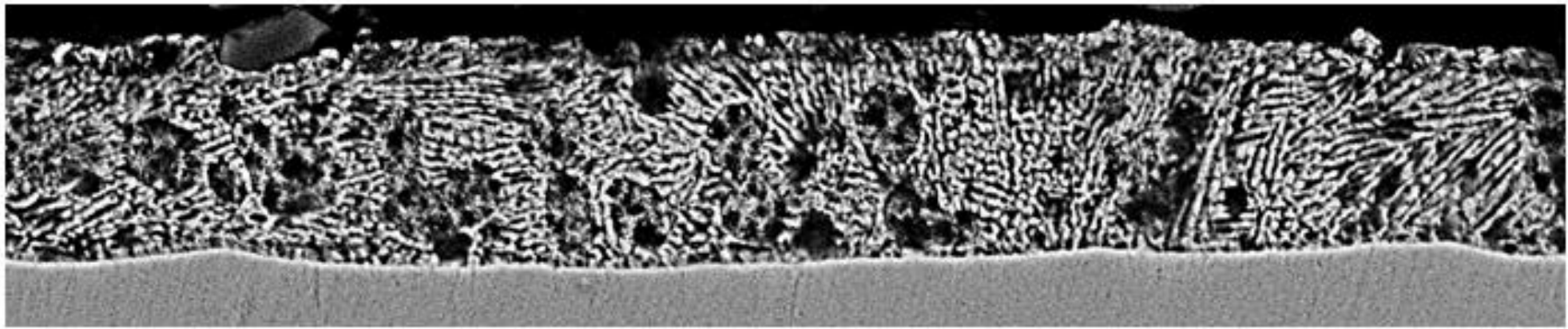

15 seconds

b.) $6 \mathrm{Al}-3 \mathrm{Mg}$ 
Coating Thickness $(\mu \mathrm{m})$

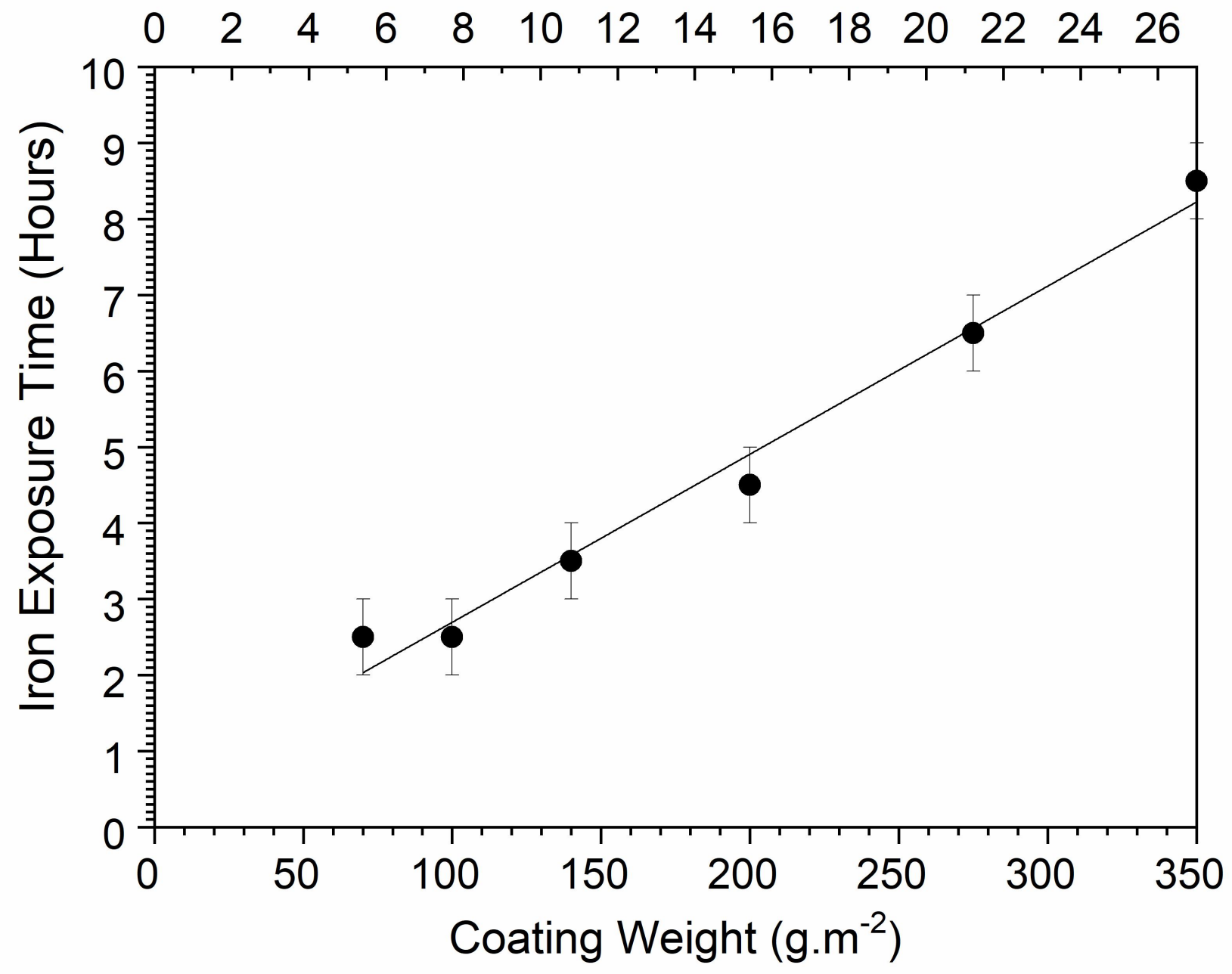



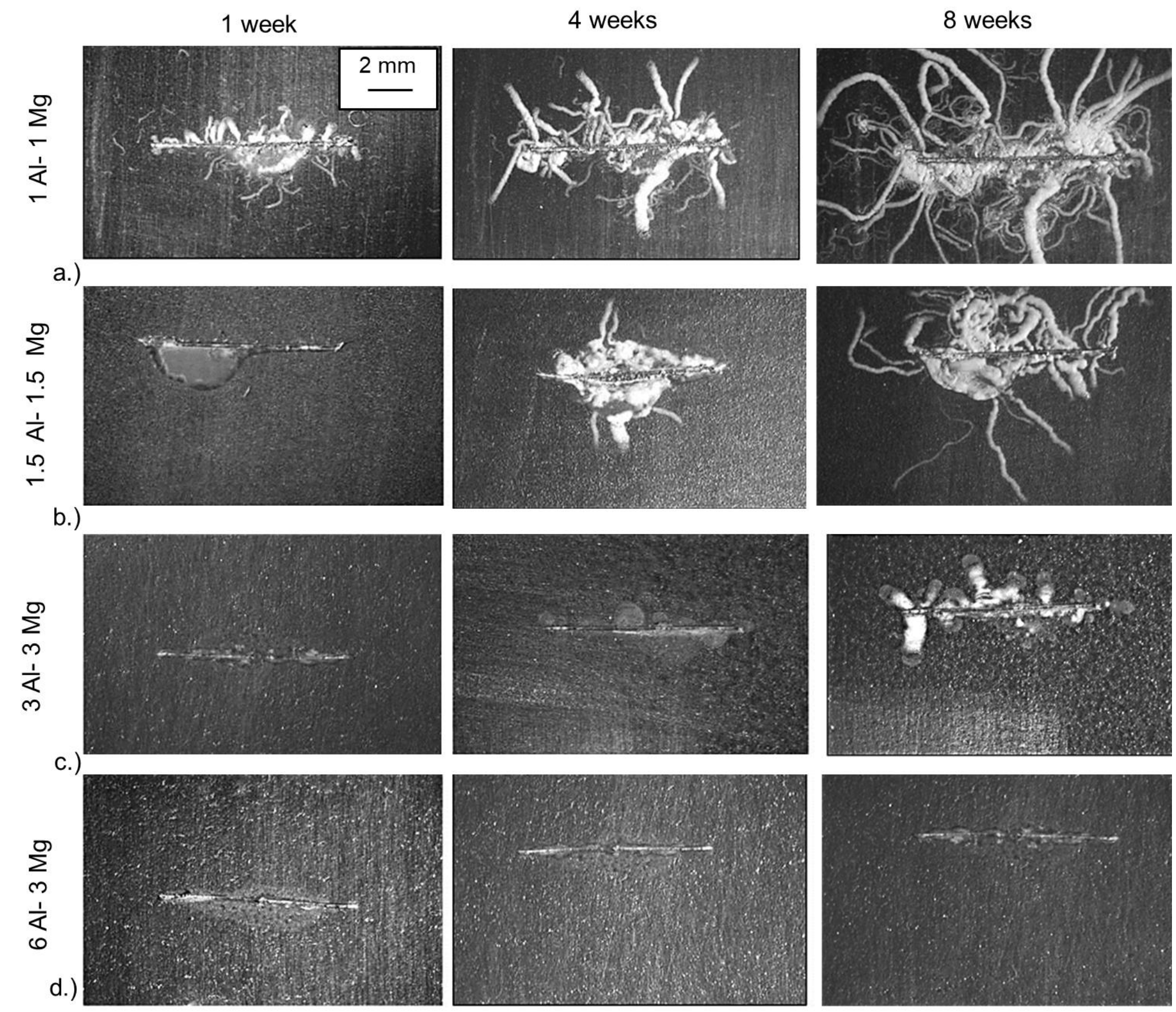


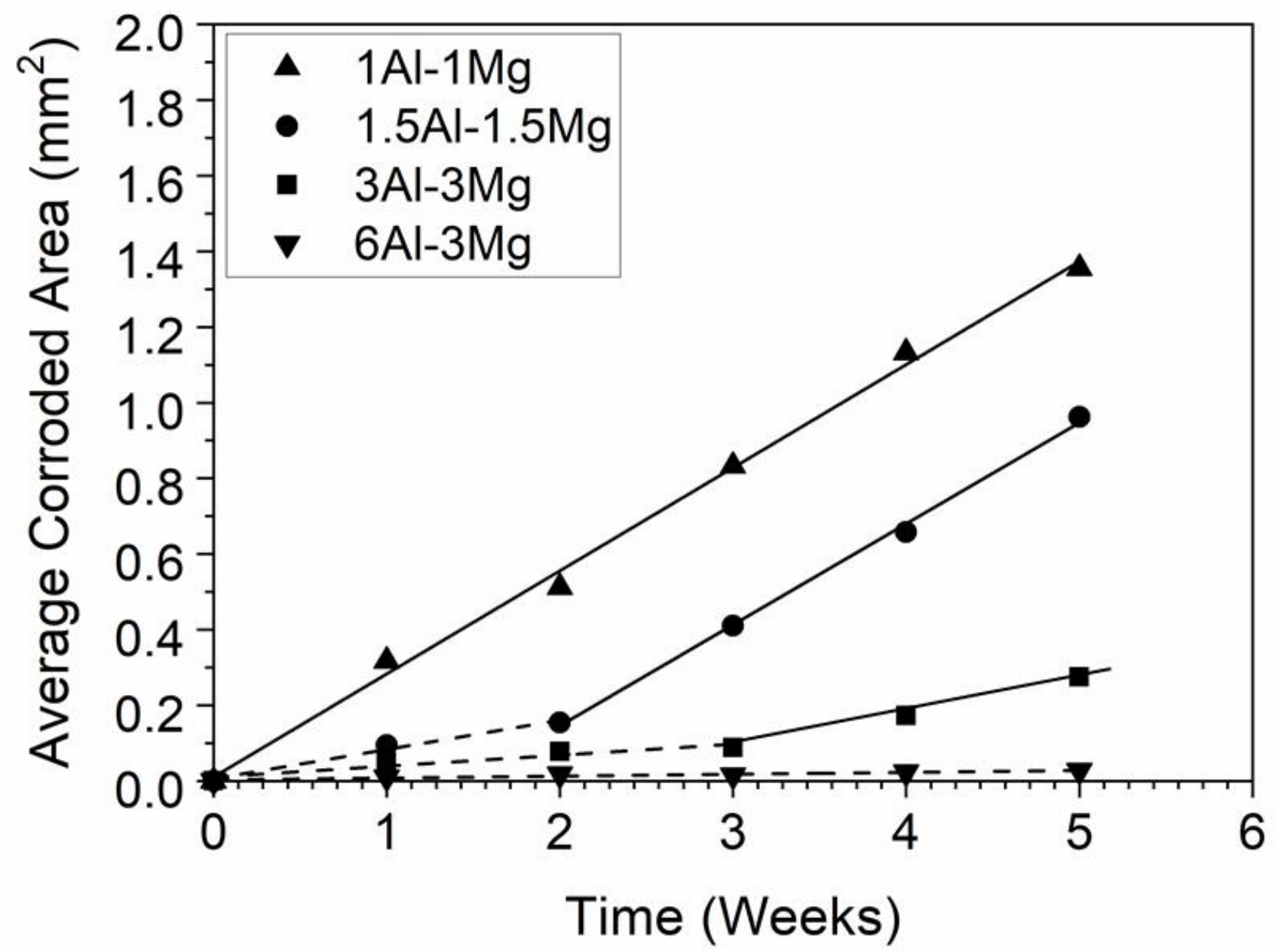




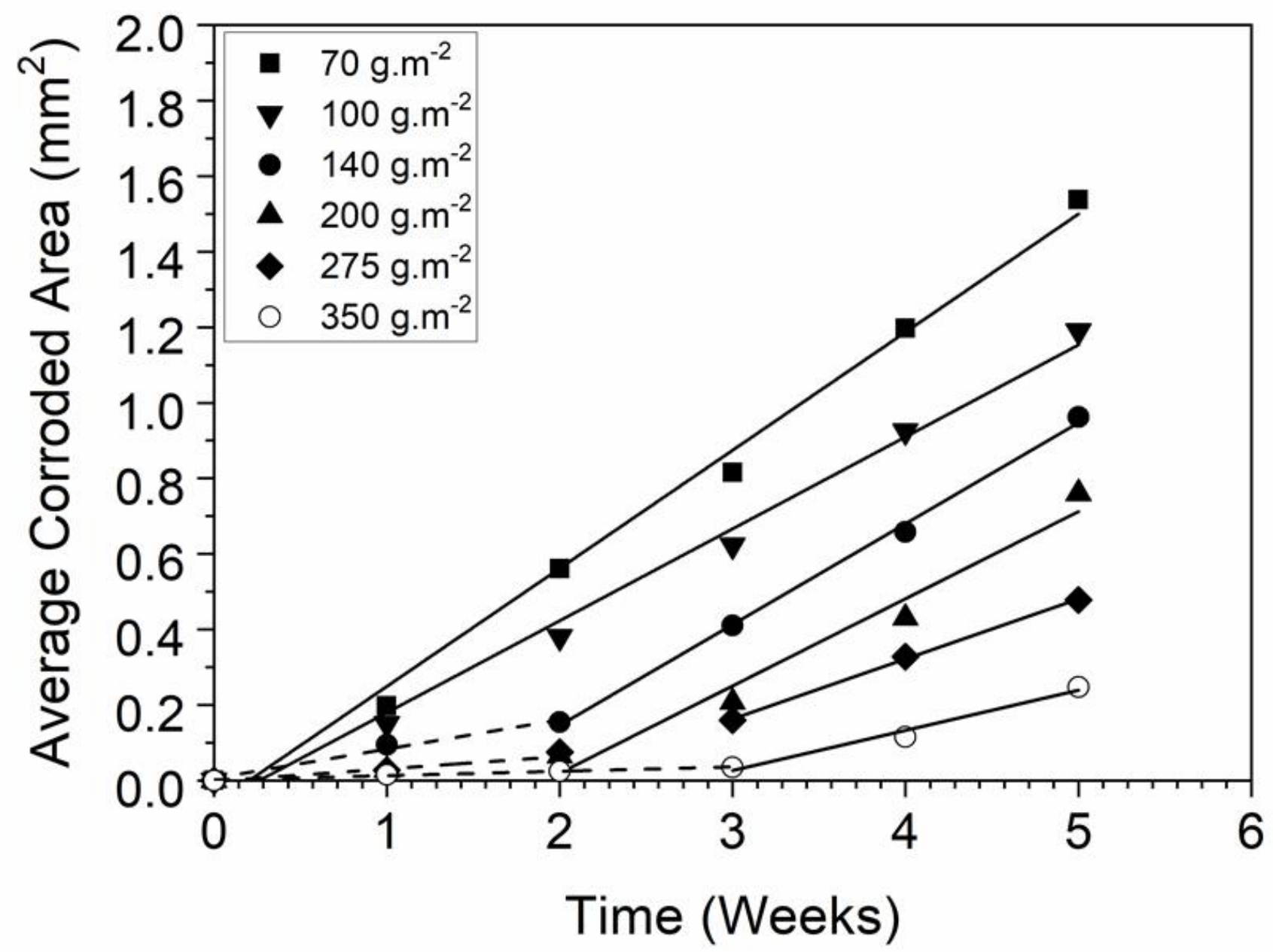




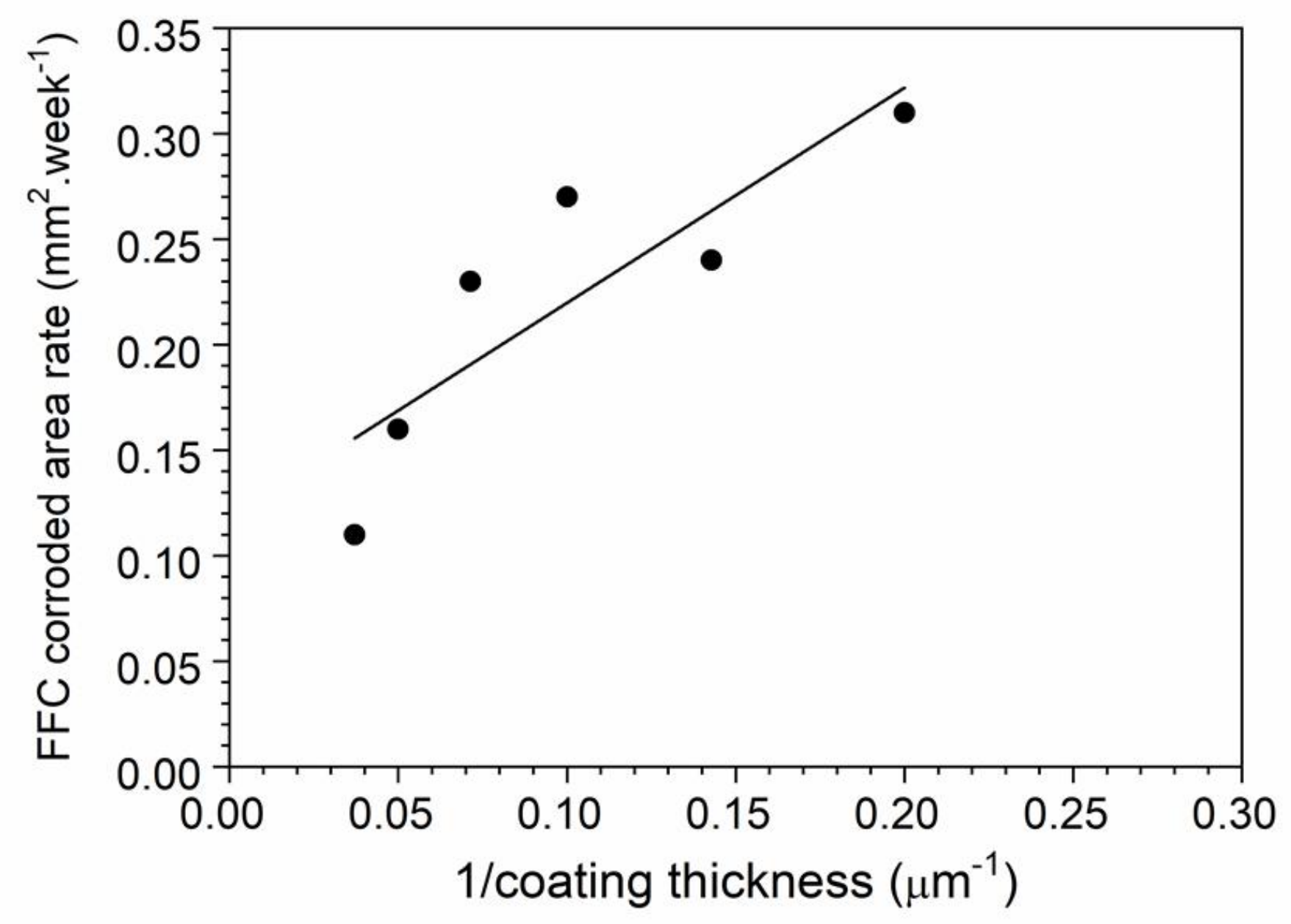

